PAWEE T. DOBROWOLSKI

Collegium Civitas, Warszawa

\title{
CYTRYNOWY JEDWAB. WDOWA HUTCHINS, ŻYDZI I PRZESTĘPCZOŚĆ ZORGANIZOWANA W LONDYNIE XVIII W.
}

Napad był dobrze przygotowany i sprawnie przeprowadzony. 0 godz. 11 wieczorem, nawet w czerwcu podlondyńską wieś Chelsea spowijały już ciemności. Okolica ta w XVIII w. uchodziła za „ogród stolicy”, słynęła z sadów, gospodarstw rolnych, pastwisk i ogrodów warzywnych (wyhodowano tam pierwszą w Anglii sałatę), a początki bardziej zwartego budownictwa - wokół królewskiego szpitala wojskowego założonego w 1694 r., powstałej w 1773 r. prywatnej szkoły kadetów w tzw. Little Chelsea (bliżej Kensington) zorganizowanej dla młodych uczniów przez Belga Louisa Lochée, manufaktury rodzimej porcelany (czynnej w latach 1750-1784), koszar wojskowych (Duke of York's Barracks) oraz budynków słynnych ogrodów botanicznych - nie zmieniły jeszcze jej wiejskiego, rezydencjalnego i wypoczynkowego charakteru. Podmiejskie okolice Londynu - w tym m.in. Chelsea czy Kensington - zamieszkiwało w 1700 r. ledwie ponad 9 tys. mieszkańców, w połowie stulecia już ponad 22 tys., a w roku 1800 ponad pięć razy więcej ${ }^{1}$. Chelsea stawała się w XVIII w. modną wilegiaturą. W 1750 r. - po latach dorabiania się majątku piórem w Londynie - przeniósł się tam, dla niższego niż w Londynie czynszu (do Monmouth House), pisarz i dziennikarz Tobias Smollett, którego medyczne wykształcenie

${ }^{1}$ Dokładne omówienie topografii i kolejnych faz budownictwa, które doprowadziły w XIX w. do włączenia Chelsea do stołecznej aglomeracji, zob. The Victoria History of the Counties of England. A History of the Country of Middlesex, t. 12: Chelsea, red. P. E.C. Croot, London 2004. Przyrost ludności w pięciu podlondyńskich parafiach (Marylebone, St. Pancras, Paddington, Kensington i Chelsea) omawiała M. Dorothy George, Some Causes of the Increase of Population in the Eighteenth Century as Illustrated by London, „The Economic Journal” 32, 1922, 127, s. 328. Na temat sławnego ogrodu botanicznego zob. P. Husting, Isaac Rand and the Apothecaries' Physic Garden at Chelsea, „Garden History" 30, 2002, 1, s. 1-23. 
mogło mu podpowiedzieć, że mieszkanie wśród zieleni i blisko Tamizy korzystnie wpłynie na zdrowie jego żony i córki. Jego sąsiadami byli m.in. złotnik z Liège Nicholas Sprimont, właściciel (1747-1769) fabryki porcelany, rosyjski ambasador, szkocki arystokrata książę Argyll oraz kompozytor Thomas Arne, autor hymnu Rule Britannia (mieszkał tam tylko przez rok $)^{2}$. Okolice zamieszkiwało też wielu oficerów i lekarzy, m.in. królewski chirurg John Ranby, znawca ran postrzałowych uwieczniony na stronach powieści Tom Jones przez Henry'ego Fieldinga, oraz wenecki „szarlatan” Bartolomeo di Dominiceti, który służył radami królewskiej rodzinie, a nad Tamiza przy ulicy Cheyne Walk ufundował i prowadził (1765-1782) modny zakład kąpielowy.

W dniu 11 czerwca 1771 r. słońce zaszło kwadrans po dwudziestej. Wdowa Elisabeth Hutchins o godz. 23 - wśród głuchej już nocy - usłyszała krzyk swojej kucharki i wielki hałas. Ruszyła, aby dowiedzieć się, co się wydarzyło, a wówczas dwóch mężczyzn schwytało ją, wcisnęło w krzesło i zadarło jej na głowę wierzchnią suknię, kiedy zaś starała się - odruchowo przywrócić ją na miejsce, jeden z napastników przytknął jej do ust lufę pistoletu i ostrzegł, że „rozwali jej głowę, jeśli się ruszy”. Drugi z mężczyzn odsunął co prawda broń od jej twarzy, ale znów zaciągnął jej suknię na głowę. Obaj poszli po schodach na górę i po chwili pani Hutchins usłyszała dwa strzały oraz hałas ciała spadającego po schodach. Przerażona rzuciła się do tylnych drzwi, wpadła jednak na dwóch innych mężczyzn, którzy krzyknęli ,jeśli nie jesteś przyjacielem, rozwalimy ci łeb” 3 .

Zburzenie domowego miru oraz napad rabunkowy z bronią w ręku, nie mówiąc już o morderstwie, którego pani Hutchins mogła się domyślać (nie wspominając o obawie o własne życie), wystarczają, aby incydent z Chelsea ocenić jako należący do kategorii przestępstw najcięższych, które angielski kodeks karny XVIII w. zaliczał do najsurowiej karanych ${ }^{4}$. Wtargniecie do domu w celu dokonania rabunku, w prze-

${ }^{2}$ L. M. Knapp, Smollett's Early Years in London, „The Journal of English and Germanic Philology" 31, 1932, 2, s. 220-227.

3 "If you are not a friend we will blow your brains out”, „Town \& Country Magazine" 3, 1771, s. 651-654. Przypadek napaści na wdowę Hutchins będę relacjonował na podstawie protokołu zeznań oraz relacji prasowych zamieszczonych w poczytnych miesięcznikach. O napadzie i jego konsekwencjach pisały: „The London Magazine” 40, 1771, s. 618-619; ,Lady's Magazine” 2, 1771, s. 267-271, , The Oxford Magazine: or, Universal Museum” 1771, 6, s. 230, ibidem, 1771, 7, s. 220-225, 236-237; „The Gentleman's Magazine” 41, 1771, s. 567; „The Scots Magazine” 33, 1771, s. 700-704. Por. streszczenie w 〈http://www.exclassics.com/newgate/ng323.htm〉. Przebieg przesłuchań za: Old Bailey Session Papers, t17711204-39 (dalej: OBSP), nr 1, dostępne w: 〈http://www. oldbaileyonline.org $>$.

${ }^{4}$ Podstawową - bardzo już dziś bogatą - literaturę na temat angielskiego systemu funkcjonowania prawa karnego w XVIII w. cytują: D. Hay, Crime and Justice in 
strzeń, która nabywała w XVIII w. znaczenia obszaru wydzielonego, uznanego za prywatny, chroniony przez zamki, skoble, zamykane okiennice i pilnie strzeżone klucze, nabierało w oczach stróżów prawa (wedle zapisów statutu z roku 1691) znamion przestępstwa karanego gardłem. Amanda Vickery przypominała, że w XVIII w. londyńczycy nadal przybijali podkowy do drzwi, aby „złe” - postrzegane jako groźba rzucenia uroku przez czarownice - nie przekroczyły progu ich domów, jednakże zagrożenia, które niosła wielka metropolia, były mniej może ezoteryczne, ale bardziej fizycznie groźne ${ }^{5}$. Kucharka Mary Hotchkins zeznawała przed sądem, że najpierw usłyszała szczekanie psa, a druga służąca, która otworzyła drzwi „przestraszyła się, uciekła i zamknęła się w salonie”. Bandyci byli zdeterminowani i bezwzględni: jeden „wsadził przez drzwi laskę, długą na sześć cali, i wtargnął do korytarza, złapał ją [kucharkę], zaciągnął do kuchni i związał", natomiast zamknięty na klucz salon także nie okazał się nie do zdobycia, ponieważ, jak zeznawała służąca, ,przyszli do niej, związali jej

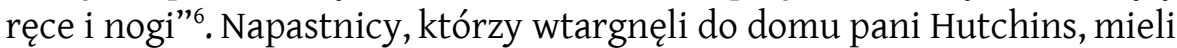
broń: ten aspekt napaści można uznać za szczególnie niebezpieczny i karalny w ocenie wymiaru sprawiedliwości. W Londynie w XVIII w. pistolety posiadało zapewne tysiące ludzi, był to jednak przedmiot - przynajmniej w teorii - „klasowo zdefiniowany”, przynależny raczej zamożnym i dobrze urodzonym. Posługiwano się nim publicznie - mimo rosnącej społecznej dezaprobaty - jako narzędziem regulowania sporów honorowych, w pojedynkach, które angielscy gentlemen toczyli ze sobą dyskretnie, o poranku, najczęściej w okolicach Hyde Parku. Chociaż wieści o tych potyczkach stawały się zaraz własnością publiczną, to użycie broni pozostawało

Eighteenth- and Nineteenth-Century England, „Crime and Justice” 2, 1980, s. 45-84; P. Linebaugh, The London Hanged: Crime and Civil Society in the Eighteenth Century, London 1991; A. T. Harris, Policing the City: Crime and Legal Authority in London, 1780-1840, Columbus 2004; A. McKenzie, Tyburn Martyrs: Execution in England, 1675-1775, London 2007; S. Devereaux, Recasting the Theatre of Execution: The Abolition of the Tyburn Ritual, „Past \& Present" 2009, 202, s. 127-174.

${ }^{5}$ Dyskusje na temat wartości „tradycyjnej” tezy mówiącej, że miasto jest obszarem zwiększonego występowania zjawisk przestępczości, podjął Peter King, The Impact of Urbanization on Murder Rates and on the Geography of Homicide in England and Wales, 1780-1850, „The Historical Journal” 53, 2010, 3, s. 671-698.

${ }^{6}$ Kucharka Hotchkins zeznała, że ,about eleven o'clock on the $11^{\text {th }}$ of June hearing the dog bark and a noise without her fellow servant went to the door [- - ] the Doctor having thrust his stick about six inches in soon rushed into the passage seized her and dragged her into the kitchen, that he tied her hands and feet”, „Town \& Country Magazine" 3, 1771, s. 652. Zob. A. Vickery, An Englishman's Home is His Castle? Thresholds, Boundaries and Privacies in the Eighteenth-Century London House, „Past \& Present" 2008, 199, s.147-173; B. Heller, Leisure and the Use of Domestic Space in Georgian London, „The Historical Journal” 53, 2010, 3, s. 623-645. 
sprawą prywatną jej użytkowników ${ }^{7}$. Korzystanie z broni palnej niosło z sobą jeszcze dwie konotacje, już zdecydowanie bardziej naganne i możliwe do opisania w kategoriach prawa.W dniu 8 maja 1783 r. poseł do Izby Gmin William Skrine, który noc spędził w elitarnym kasynie Brooke'a, udał się do jednej z oberży przy Newgate street i strzelił sobie w głowę, nie mogąc pogodzić się z poniesionymi stratami. Za broń często sięgali więc dobrze urodzeni desperaci, samobójcy, których zawiodła fortuna (Skrine był synem bogatego lekarza). Miesięcznik „The London Magazine” opublikował wykaz osób, które w 1768 r. uznano za zmarłe wskutek nieszczęśliwych wypadków. Wedle tego wyliczenia utopiło się 115 londyńczyków, a 71 poniosło śmierć w skutek groźnych upadków. Następną kategorią byli właśnie samobójcy, których naliczono 28 (dla porządku dodajmy, że 4 osoby zapiły się

7 „The Gentleman's Magazine” podawał, że w sobotę 13 maja 1769 r. „dwóch gentelmanów stoczyło pojedynek w Hyde Parku z powodu kłótni w Vauxhall,jeden otrzymał pchnięcie w prawe ramię, drugi został trafiony w udo, po czym rozdzielili ich sekundanci” („A duel was fought between two gentlemen in Hyde-Park, occasioned by a quarrel at Vauxhall, one of them was run thro' the sword-arm, and the other was wounded in the thigh, after which they were parted by their seconds”), „The Gentleman's Magazine" 39, 1769, s. 269. W dniu 3 lutego 1773 r. na polach Marylebone strzelali się lord George Townshend (z zawodu żołnierz) i Charles Coote hr. Bellomont, który otrzymał ciężką ranę. Zasady „grzeczności” były jednak respektowane przez obu, co relacjonowano w „Universal Magazine” 1773, 52, s. 105-106 oraz w „The London Magazine" 42, 1773, s. 97-98. Po kłótni w tawernie Star and Garter przy Pall Mall doszło do pojedynku, w wyniku którego zmarł żałowany przez gazetę p. Chaworth, a jego zabójca lord Byron stanął przed Izbą Lordów. Sprawa była gruntownie opisywana, zob. „The Gentleman's Magazine” 35, 1765, s. 45, 143, 196, 227-229, oraz w „Universal Magazine" 1765, 36, s. 220. W oberży Adelphi na Strand 14 stycznia 1777 r. w zamkniętym pokoju strzelali się (o honor kobiety) redaktor „Morning Post” Henry Bate i kpt. Stony, obaj chybili i chwycili za białą broń, w: „The Gentleman's Magazine” 47, 1777, s. 43. Inny pojedynek oficerów na pistolety, ibidem, 35, 1765, s. 441. „The London Magazine” 43,1774 , s. 46 relacjonował pojedynek oficerski w Irlandii z powodu zarzucenia jednemu z uczestników, że „,jest Cyganem”. James E. Fox, który strzelał się 29 listopada 1779 r. w Hyde Parku z posłem do Izby Gmin Williamem Adamem, został lekko ranny i stwierdził: „Bez wątpienia bym zginął, gdyby Pan Adam używał innego niż rządowy proch", za: A. Sherbo, From the Westminster Magazine: Swift, Goldsmith, Garrick, Et Al., "Studies in Bibliography” 41, 1988, s. 274. Por. S. Banks, A Polite Exchange of Bullets: The Duel and the English Gentleman, 1750-1850, Woodbridge 2010.

Szermierkę propagowano jako sztukę obronną, nieodzowną wykształconemu szlachcicowi. Szkołę fechtunku założył w Londynie w 1763 r. Włoch Domenico Angelo, autor L'École des armes (Londres 1763), zob. R. B. Shoemaker, The Taming of the Duel: Masculinity, Honour and Ritual Violence in London, 1660-1800, „The Historical Journal” 45, 2002, 3, s. 530. Boks jako sposób walki szlachetnie urodzonych - popularny w połowie XVIII w. - wyszedł z mody pod koniec wieku, zob. R. B. Shoemaker, op. cit., s. 529; J. M. Beattie, Crime and the Courts in England, 1660-1800, Princeton 1986, s. 91 nn. Ewolucje postaw wobec pojedynków zob. Men and Violence: Gender, Honor, and Rituals in Modern England and America, red. P. Spierenburg, Columbus, Ohio 1998; M. Peltonen, The Duel in Early Modern England: Civility, Politeness and Honour, New York 2003. 
na śmierć, 3 zażyły truciznę (lub zostały otrute), 3 zmarły z głodu, 2 zostały zastrzelone, a 1 zmarła na skutek pogryzienia przez wściekłego psa) ${ }^{8}$. Pistolet był też stałym wyposażeniem i narzędziem pracy owianych „romantyczną” aurą highwaymen, drogowych rabusiów, którzy napadali podróżnych na królewskich traktach i kpili (do chwili aresztowania, ale i „brawurowo” potem) z wymiaru sprawiedliwości. Za takie przestępstwa karano ich bez sentymentów, stryczkiem ${ }^{9}$. Napastnicy z Chelsea używali

${ }^{8}$ Por. notatkę prasową o zastrzeleniu się z pistoletu (po nieudanej nocy przy kartach): „On Saturday last - O'Neal, Esq; lately arrived from the West Indies, in a fit of insanity, shot himself through the head, and expired immediately; the cause of this rash action is not to be accounted for, unless by a stroke of ill luck the preceding night”, „The Oxford Magazine” 1771, 7, s. 75, zob. wykaz nieszczęśliwych wypadków w „The London Magazine” 38, 1769, s. 652. Por. J. Landers, A. Mouzas, Burial Seasonality and Causes of Death in London 1670-1819, „Population Studies” 42,1988, s. 59-83. O samobójstwach zob. M. MacDonald, The Secularization of Suicide in England, 1660-1800, „Past \& Present" 1986, 111, s. 50-100.

${ }^{9}$ Bronią posługiwano się także w wielu „miejskich” napadach rabunkowych. Por. przykładowe relacje: „W niedzielę wieczorem [tj. 1 VII 1771 - P.T.D.] w parku św. Jakuba kobieta uzbrojona w pistolet zatrzymała pewnego pana [gentleman] i ograbiła go z pary spinek i notesu z kilkoma banknotami. Została zatrzymana przez strażników, przewieziono ją do urzędu na Bow street, a potem do więzienia” (,Sunday night a gentleman was stopt by a woman in St. James's-park, armed with a pistol, who robbed him of a set of paste buckles and a pocket book, containing several notes; she was taken into custody by one of the centiels, and being yesterday carried before the magistrates in Bow-street was committed to Tothill-fields Bridewell”) oraz „wczoraj rano [10 VII 1771 - P.T.D.] około jedenastej śmiały zbój, małego wzrostu, ubrany na czarno i ze śladami ospy zapukał do drzwi pana Stonil, urzędnika akcyzy, który mieszka przy Cross street przy rynku Carnaby, i powiedział pani Stonil, że przychodzi od męża (który wyszedł koło dziewiątej), podał miejsce jego pobytu i prosił o przysłanie wszystkich pieniędzy z poprzedniego dnia, będzie tego z 18 funtów, oraz innych, tak dużo, jak może zebrać. Pani Stonil zgodziła się i powiedziała, że sama też pójdzie i ruszyła ku szafie [bureau], na co bandyta rzekł: «Nie do cholery [damn you], nie tak będzie, miałem być grzeczny, ale chcę pieniędzy», i wydobył pistolet, powalił ją, zawlókł do łóżka (w pokoju z tyłu), przywiązał fartuchem do oparcia, o które walił jej twarzą, i przysiągł, że rozwali jej głowę, jeśli będzie hałasować. Opróżnił potem szafę z około 25 funtów i uciekł nierozpoznany” („Yesterday morning, about eleven o'clock, a daring villain, a little man in black, and pitted with the small-pox knocked at the door of Mr. Stonil, officer in the Excise, who lives in Cross-street, Charnaby market, and told Mrs. Stonil he came from her husband, (who went out about nine) that he was at such a place, and had sent him for all the money he received yesterday, it being about $18 £$ and as much more as she could spare. She replied yes, and said she would go along with him, and was going towards the bureau; on which the villain said: «No, d-n you, that will not do; I thought to have used you civilly; but I want the money»; and presented a pistol, knocked her down, dragged her to the bed (which was in the back parlour) and tied her to the bed-post with her apron, beating her face against it, swearing if she made the least noise, he would blow her brains out; then stripped the bureau of about $25 £$ and got off undiscovered”), „The Oxford Magazine” 1771, 7, s. 36, 38. Na temat przestępczości kobiet zob. U. Rublack, The Crimes of Women in Early Modern Germany, Oxford 1999; J. M. Beattie, The Criminality of Women in Eighteenth-Century 
broni w sposób bezwzględny: pistoletami zastraszyli panią Hutchins, a oddane strzały świadczyły, że nie cofali się przed ich użyciem, zabijając jednego z jej domowników. Idący w setki przypadków, możliwy do spisania katalog londyńskich napadów rabunkowych z XVIII w. rzadko wymieniał użycie broni - znacznie częściej bez strzelaniny po wyłamaniu drzwi, sforsowaniu zamków lub okien złodzieje kradli wszystko, co wpadło im w ręce, najczęściej przedmioty pozostawione na widoku: pościel, ubrania, zastawę stołową, przedmioty wartościowe i drobne pieniądze. Sprawa napadu w Chelsea, podobnie jak wiele innych zapisów źródłowych osadzonych w poetyce sali sądowej, stanowi dla historyków nie tyle możliwość analizowania historycznie zmiennej dynamiki procedur prawa, rozpoznanej już z dużą dokładnością, ile podejmowania tropów prowadzących do zjawisk kultury masowej, mieszczących się „ponad” lub „obok” wydarzeń opisywanych językiem właściwym dla systemu sprawiedliwości. Zapisy sądowe funkcjonują niczym soczewka, dzięki której ujawniają się ludzkie postawy i sytuacje należące do domeny social dramas, ukazują na krótko - bohaterowie pojawiają się zwykle jednorazowo w polu historycznego widzenia - sceny pełne napięcia, tym bardziej zatem wiarygodne są dla ustalenia codziennych i niecodziennych zachowań, zwyczajów myślenia, reagowania i działania. Jak pisała Dana Rabin, sala sądowa w osiemnastowiecznej Anglii jest „miejscem, gdzie tworzy się kultura, a szczególnego znaczenia w tym procesie nabierają emocje"10.

Zeznania przed sądem, zwłaszcza w kontekstach „kryzysowych”- tzn. takich, które dotyczyły odpowiedzialności za wypowiadane słowa lub opi-

England, „Journal of Social History” 8, 1975, s. 80-116; G. Durston, Victims and Viragos: Metropolitan Women, Crime and the Eighteenth-Century Justice System, Bury St. Edmunds 2007. Malcolm M. Freely i Deborah L. Little (iidem, The Vanishing Female: The Decline of Women in Criminal Process, 1687-1912, „Law \& Society Review” 25, 1991, 4, s. 719-757) stawiali tezę o gwałtownym spadku liczby kobiet-przestępców między XVII a XIX w., zob. też P. King, Crime and Law in England, 1750-1840: Remaking Justice from the Margins, Cambridge 2006, rozdz. 6 .

Losy słynnej bandy Turpina rekonstruował Derek Barlow, Dick Turpin and the Gregory Gang, London-Chichester 1973. Migracje legend i eksplozję literatury „bandyckiej” omawiał Lincoln B. Faller, Criminal Opportunities in the Eighteenth Century: The "Ready-Made" Contexts of the Popular Literature of Crime, "Comparative Literature Studies” 24,1987, 2, s. 120-145; idem, Turned to Account: The Forms and Functions of Criminal Biography in Late Seventeenth-and Early Eighteenth-Century England, New York 1987. Por. M. Harris, Trials and Criminal Biographies: A Case Study in Distribution, w: Sale and Distribution of Books from 1700, red. R. Myers, M. Harris, Oxford 1982, s. 1-36; G. Spriggs, Outlaws and Highwayman: The Cult of the Robber in England from the Middle Ages to the Nineteenth Century, London 2001; G. Howson, Thief-Taker General: The Rise and Fall of Jonathan Wild, New York 1970.

${ }^{10}$ D. Y. Rabin, Identity, Crime and Legal Responsibility in Eighteenth-Century England, New York 2004, s. 4. 
sywały stany zagrożenia, konfrontacji i lęku, funkcjonują jako teksty historycznie osadzonej kultury oraz stają się autentycznym zapisem ludzkiej kondycji. Także w tym przypadku interesujące okażą się te sytuacje, których odtworzenie będzie możliwe dzięki analizie akt sprawy. Nie zawsze jednak udzielą one odpowiedzi na wszystkie wątpliwości i pytania. Interesować nas będzie zarówno „technologia i logistyka napadu"11, struktura grupy przestępczej, z którą mamy do czynienia, „konfabulacje” i zniekształcenia dokonane przez specyficzne narzędzie przekazu, jakim się posługujemy - prasę - która przetwarzała zapis sądowy (pytań i odpowiedzi) w zwarty tekst, a także próba odpowiedzi na pytanie o społeczną kondycję przestępców i ofiary oraz ich miejsce w strukturze podlondyńskiego obszaru zamożności. Czy łatwiej było napaść na wdowę dlatego, że jako kobieta, a zarazem głowa domu stanowiła łatwy cel? Uzbrojenie i liczba napastników przeczyłyby takiemu założeniu. Może więc jej status (wdowieństwo) stanowił pokusę, związaną z wyobrażeniami o zamożności właścicielki wiejskiego gospodarstwa? Po wtóre interesować nas będzie sam proces, który okaże się pełen nieoczekiwanych zwrotów. Będzie więc mowa o wyimaginowanym bogactwie oraz o zwykłym codziennym losie paserów i złodziei, o konfrontacji oskarżonych ze świadkami, która przybierze gwałtowną (w słowach) postać, a także o samym wymiarze sprawiedliwości, który okaże swoją siłę i zdolność wywierania wpływu na ludzkie postawy i charaktery.

${ }^{11}$ Por. zapis prasowy podobnego, równie dramatycznego napadu (ale w centrum miasta, opodal katedry św. Pawła): „W ubiegły poniedziałek [25 III 1771 - P.T.D.] między 8 a 9 wieczorem dwóch zbójców [desperate villains] zapukało do mieszkania pani Cope na Oxford Court przy Cannon street. Kiedy pokojówka otworzyła,jeden z nich powiedział, że przyniósł list dla jej pani, a kiedy ruszyła po schodach, a on za nią, pani Cope była na tyle przytomna, by zamknąć drzwi na klucz w chwili kiedy się wpychał, aż przycięła mu kawałek płaszcza. Wówczas wspólnik wyciągnął pistolet i wycelował w drugą służąca, grożąc że wypali jej w głowę, zawołała jednak: «złodzieje» i złapała go za kołnierz, próbując wyrwać mu pistolet. Wypalił do niej, ale pistolet spalił na panewce i zaalarmował sąsiadów [- - ] obaj wybiegli z domu, bez łupu, a kiedy zatrzymał ich służący, wycelowali w niego pistolet i umknęli” („Monday evening last, between Eight and Nine o'clock, two desperate villains knocked at the door of Mrs. Cope, in Oxford Court, Cannon-street. One of the fellows, on the maid opening the door, said he had a letter for the lady. On the maid going up stairs to inform her mistress, hearing him following up to the chamber, Mise Cope had the presence of mind to lock the door, at the instant he was forcing in, and left part of his coat shut in; at the same time an accomplice presented a pistol to the other maid on the stairs, and threatened to blow her brains out if she spoke a word; immediately she cried «Thieves!» and collared him, and endevouring to wrest a pistol out of his hand, he fired at her, but the pistol only flashed in the pan, this alarming the neighbourhood, they precipitately ran out of the house without their booty; they were stopped by a man servant, but on presenting a pistol to him, both escaped”), „The Oxford Magazine” 1771, 6, s. 120. 
Po sześciu miesiącach od napadu podejrzani znaleźli się za kratkami. Ocena sprawności angielskiego, przede wszystkim stołecznego systemu wykrywania przestępstw pozostaje w kontekście XVIII w. nadal tematem otwartym i często analizowanym. Największe miasto Europy obywało się bez policji, nadal korzystając z dawniejszych, dzielnicowych i parafialnych mechanizmów obywatelskiej czujności, choć eksperyment braci Fieldingów oraz ich ,prywatny” (ale subsydiowany przez Parlament) aparat "gońców z ulicy Bow" - skutecznych także w sprawie z Chelsea wskazywał na coraz bardziej dostrzeganą potrzebę powołania do życia instytucji osadzonych w miejskim porządku prawnym, a co za tym idzie, wysłania na ulice płatnych i „zawodowych” stróżów prawa. Prawnik William Mildmay, który wiele lat spędził w Paryżu, starał się w 1763 r. przekonać Anglików, że niechętnie widziany nad Tamizą model burboński kontrola, dzięki stałej (w dzień i w nocy) obecności policjantów, regularna inwigilacja dzielnic i przybytków uznanych za podejrzane, a nawet reglamentacja obywatelskich wolności - wpisuje się w potrzeby wielkiej aglomeracji i definiuje nowoczesny system zarządzania i nadzoru (stąd francuskie policie), który mimo znacznego wydatku (model paryski szacował na ponad 55 tys. funtów rocznie) przynosi korzyść w postaci odpowiedniego „uregulowania” społeczeństwa ${ }^{12}$. „Wynalazek” braci Fielding - powołanie do życia sprawnej instytucji ścigania przestępców, opierając się na królewskim mandacie sprawowania funkcji sędziów pokoju dla Westminster oraz „przedstołecznego” obszaru hrabstwa Middlesex - polegał, także w przypadku napadu w Chelsea - na szybkim rozpoznawaniu wykroczeń, odnalezieniu i zatrzymaniu winnych, przesłuchaniu oraz przekazywaniu podejrzanych o najcięższe, karane gardłem przewiny do dalszego rozpatrzenia (i osądzenia) przez karny trybunał, działający przy więzieniu Old Bailey. Drobniejsze przypadki rozstrzygał sam sędzia (i znany pisarz) H. Fielding (a potem, po jego śmierci, jego młodszy brat). Jak wyliczył jeszcze w 1954 r. Archibald Shepperson, tylko w okresie trzech miesięcy (1747-1748) starszy z Fieldingów wydał orzeczenia w 64 przypadkach (na 185 spraw) odnoszących się - zgodnie z jego mandatem sędziego pokoju - przede wszystkim do mniejszych wykroczeń, tzn. takich, które nie były karane gardłem. Skazywał drobne złodziejki, osoby winne wykroczeń obyczajowych, domowej przemocy oraz ulicznych bójek i napaści (np. sądził Mary Anstie, która ugryzła Jamesa Thwaitta w nogę), wydając wyroki

${ }^{12}$ W. Mildmay, The Police of Paris, or An Account of the Laws \& Regulations Established in that Kingdom for the Preservation of Peace and the Preventing of Robberies, London 1763, zwł. s. 46-60, 123 nn. Por. J. Chagniot, Le Guet et la Garde de Paris à la fin de l'Ancien Régime, „Revue d'histoire moderne et contemporaine” 20,1973, s. 58-71 (wśród paryskich policjantów odnalazł jednego urodzonego w Londynie oraz jednego - w Polsce, s. 64). 
deportacji, nacechowania żelazem i publicznego batożenia. W przypadku spraw obciążonych wyższa karą - jej wymiar w przypadku przestępstw przeciw mieniu był w XVIII w. uzależniony m.in. od wartości skradzionych przedmiotów - rozpoznawano je w areszcie przy Bow street (Fielding mieszkał na piętrze, a sądził na parterze), a potem przekazywano wraz z dokumentacją do wyższej instancji, królewskiego karnego trybunału umiejscowionego przy największym stołecznym więzieniu w old Bailey ${ }^{13}$.

Schwytanie bandytów, którzy napadli na wdowę Hutchins, zajęło nieco czasu, jednak w piątek 6 grudnia 1771 r. o dziesiątej rano trybunał karny z sędzią Perrotem na czele przystąpił do rozpoznania sprawy o napad i morderstwo. Na ławie oskarżonych zasiadło sześciu londyńskich Żydów: nazywany lekarzem Levi Weil, jego brat Asher, Jacob Lazarus, Marcus Hartogh, Lazarus Harry i Solomon Porter. Sąd miał trudności z ustaleniem ich tożsamości: trzeci z oskarżonych figurował także pod nazwiskami Hyam Dresden i Hyam Lazarus, czwarty nosił też nazwisko Asheburgh, a ostatni znany był jako również jako Solomon Moses (Porter, czyli „tragarz”, mogłoby sugerować jego zawód). Przed królewskim sądem stanęli oskarżeni, z których większość nie umiała sprawnie posługiwać się językiem angielskim. Język, którym mówili, określono jako „high Dutch", co mogło oznaczać dialekt niemiecki (przydomek Jacoba Lazarusa - Dresden - może stanowić wskazówkę pochodzenia geograficznego), albo nawet jidysz, który był podstawowym sposobem komunikowania się wspólnoty aszkenazyjskiej w Londynie. Pochodzili z niej wszyscy oskarżeni. Nawet przełożeni głównego ośrodka londyńskich Aszkenazyjczyków, synagogi przy Duke Place, nie radzili sobie z barierą języka. Urodzony w Rzeszowie Zevi Hirsch, rabin tej wspólnoty w latach 1756-1764, kształcił się w Głogowie, znał oczywiście hebrajski oraz jidysz, ale angielski bardzo słabo. Jego następca Dawid Tevele Schiff pochodził z Frankfur$\mathrm{tu}$, przez wiele lat przebywał w Wormacji i mimo wieloletniego (17651791) pobytu w Londynie nie opanował tego języka, często jednak przeplatając swój jidysz angielskimi słowami ${ }^{14}$.

Sąd odwołał się do pomocy tłumacza, którym został pan Myers - zapewne chodziło o Mosesa Myersa, później rabina tzw. nowej synagogi

${ }^{13}$ A. B. Shepperson, Additions and Corrections to Facts about Fielding, „Modern Philology" 51, 1954, 4, s. 217-224, Por. W. B. Coley, Fielding's Two Appointments to the Magistracy, „Modern Philology” 63, 1965, 2, s. 144-149; J. M. Beattie, Sir John Fielding and Public Justice: The Bow Street Magistrates' Court, 1754-1780, ,Law and History Review” 25, 2007, 1, s. 61-100.

${ }^{14}$ C. Duschinsky, The Rabbinate of the Great Synagogue, London, from 1756-1842, „The Jewish Quarterly Review" 9, 1918, 1/2, s. 104-106; 10, 1920, 4, s. 454, 468. 
Aszkenazyjczyków w Londynie - jednego z parnasim synagogi, którego w aktach procesowych nazwano "gwardianem"15.

Trudności językowe okazały się w czasie procesu jednym z argumentów, którym oskarżeni usiłowali się posiłkować. Oskarżony Asher Weil - który nie znał angielskiego - zarzucił oburzonemu tymi słowami tłumaczowi, że „bardziej barwnych słów używa, niż być powinny”. Ponadto oskarżeni nie chcieli „podnieść ręki”, aby złożyć przysięgę. Zapewne jej nie rozumieli, a ponadto zawierała ona odwołania do obcej im wiary. Sędzia Perrot uznał jednak, że wystarczy, aby odpowiadali „zgodnie ze swoimi nazwiskami". Nie był to jedyny przypadek, kiedy sąd musiał pokonywać barierę różnic kulturowych. Prasa donosiła, że zanim doszło do okazania oskarżonych ich ofierze, „wszyscy zostali ogoleni [--] ale i tak rozpoznała ich natychmiast"16.

Wezwana do złożenia zeznań poszkodowana Hutchins opisała, jak to H. Lazarus zadarł jej suknie na twarz, przyłożył pistolet i groził śmiercią, a doktor Weil, który zdawał się jej mniej agresywny, odsunął lufę od jej głowy i zgodził się, aby nie pętać jej nóg. Wdowa wspomniała także, że po wtargnięciu do domu napastnicy wlekli kucharkę po ziemi, bluźniąc, przeklinając i grożąc jej śmiercią, jeśli nie będzie cicho. Mimo strachu pani Hutchins „błagała ich, aby mówili do [kucharki] głośniej, że jej nie skrzywdzą, ponieważ jest nieco przygłucha”. Po nieudanej próbie wymknięcia się z domu pani Hutchins znów znalazła się na krześle. Zeznawała, że „Levi Weil, Hyam Lazarus oraz trzeci [którego nie złapano - P.T.D.] zeszli do niej i Levi Weil odpiął sprzączki z jej butów i zabrał zegarek. Mieli przeszukać jej kieszenie, ale błagała, żeby tego nie robili i powiedziała, że da im coś bardziej cennego. Poszła z nimi po schodach i dała sakiewkę, w której było 61 gwinei. Potem zeszli i zażądali jej zastawy stołowej, wyjęli z szafy, ale było tego mało i znów przyłożyli jej pistolet, rozcięli wargę i wybili ząb. Levi Weil, już drugi raz odsunął [od niej] pistolet, a człowieka, który [przyłożył jej broń] wyrzucił z pokoju"17.

${ }^{15}$ C. Duschinsky, op. cit., 10, 1920, 4, s. 485.

${ }^{16}$ „All the Jews now in prison, charged with the robbery at Mrs. Hutchins's, at Chelsea, were all shaved before they were sworn to by Mrs. Hutchins: notwithstanding which, she knew them immediately”, „The Oxford Magazine” 1771, 7, s. 198; „The Scots Magazine" 33, 1771, s. 701.

17 „one of them struck me in the face with a pistol, and was going to shoot me, for he put in finger in the trigger [--] he cut my lip with the pistol, and loosened one of my teeth”, w: OBSP; „Levi Weil, Hyam Lazarus and a man whom she described (but who is not taken) came down to her, Levi Weil took the buckles out of her shoes and her watch and were about to search her pockets which she begged them not to do declaring she would give them something better worth their notice, she went up the 
Obecność i „widzialność” Żydów nie była w osiemnastowiecznym Londynie zaskoczeniem. Jednym - przeważnie sefardyjskiej mniejszości udawało się zakotwiczyć w środowisku kupieckiego i finansowego biznesu, gdzie odnosili spektakularne sukcesy, często porzucając przynależność do religijnej wspólnoty, innym - w coraz większej liczbie pochodzącym z aszkenazyjskiej biedoty ze środkowej i wschodniej Europy - pozostawała ich własna, zamknięta kulturowo, obyczajowo i społecznie przestrzeń. Odrzucenie tradycji i wiary oraz kulturowa asymilacja były szansą na oddalenie się od świata ulicznych sprzedawców, obnośnych handlarzy tandetą, woskiem, prezerwatywami czy tanimi broszurami na rzecz lichwy (przynajmniej na $8 \%$, a nie ustawowe 5\%), wysoko oprocentowanych - czyli nielegalnych - pożyczek i obrotu pieniądzem. Kariery wielkich żydowskich finansistów działających w Londynie XVIII w. - Samsona Gideona, Josepha Salvadora, a potem braci Goldsmid wskazywały drogę prowadzącą do przełamania ukrytego (i jawnego) antysemityzmu, wyrwania się ze świata gospodarki ulicznej oraz lichwiarskiej ekonomii w kierunku ,prawdziwych” pieniędzy, rządowych kontraktów, krociowych dochodów ${ }^{18}$.

Kilkutysięczna diaspora początkowo dysponowała w Londynie dwiema synagogami: starszą, sefardyjską (portugalską) przy ulicy Bevis Marks (z 1701 r.) i drugą, wielką synagogą przy Duke's Place na rogatce Aldgate, zbudowaną w 1721 r. przez Aszkenazyjczyków z Niemiec i Wschodniej Europy. Środowisko ich było wewnętrznie podzielone,

stairs with them and gave them a purse containing 61 guineas, than they came down demanding where her plate was, she told them, they took it out of her cupboard and on finding so little a pistol was again clapped to her mouth, when Levi Weil a second time put it aside and thrust the person who presented it out of the room”, „The London Magazine” 40,1771, s. 618; "Mrs Hutchins begged them to signify loudly to her maid that they would not hurt her as she was hard of hearing”, „Town \& Country Magazine” 3, 1771, s. 651. Kucharka zeznała, że „doktor” był pierwszym, który wtargnął do domu. Starania wdowy Hutchins, aby utrzymać sukienkę w odpowiednim miejscu, oraz lęk przed „rewizją” osobistą mogą wskazywać na wątek obawy przed gwałtem. Jak wskazywali Susan Staves i Simon Dickie, twórczość pisarza (i sędziego) H. Fieldinga obfitowała w sceny prób gwałtu, a jego niewybredne żarty na ten temat potwierdzały, że przestępstwa na tle seksualnym z trudem wpisywały się w katalogi czynów uznawanych przez wymiar sprawiedliwości za wykroczenia karalne, zob. S. Staves, Fielding and the Comedy of Attempted Rape, w: History, Gender and Eighteenth-Century Literature, red. B. Fowkes Tobin, Athens, Ga. 1994, s. 86-112; S. Dickie, Fielding's Rape Jokes, „The Review of English Studies” 61, 2010, 251, s. 572-590. Por. A. E. Simpson, Popular Perceptions of Rape as a Capital Crime in Eighteenth-Century England: The Press and the Trial of Francis Charteris in the Old Bailey, February 1730, „Law and History Review” 22, 2004, 1, s. 27-70.

${ }^{18}$ M. Woolf, Joseph Salvador, ,Jewish Historical Society of England Transactions” 21, 1968, s. 104-138. Por. T. M. Endelman, The Jews of Georgian England, 1714-1830, Ann Arbor 1999 , s. $118 \mathrm{nn}$. 
rabin wielkiej synagogi - Dawid Tevele Shiff - spierał się z przywódcą kahału „hamburskiego", urodzonym w Altonie, a przedtem rabbim w Podhajcach Meshullamem Zalmanem, który w latach 1765-1780 stał na czele konkurencyjnej wspólnoty. W Londynie mieszkał także słynny baal shem, pochodzący zapewne z Podola cudotwórca, mistyk i kabalista Samuel Falk, który jednak trzymał się raczej z dala od skłóconych ${ }^{19}$. Aszkenazyjczycy byli w Anglii pariasami. Urodzeni poza Anglią, nie mogli nabywać ziemi oraz nieruchomości, formalnie obowiązywał ich zakaz zajmowania się kolonialnym handlem, w Londynie nie mogli nabyć praw miejskich i zajmować się nawet handlem detalicznym, sprawować urzędów publicznych i głosować. Podział etniczny i językowy - Aszkenazyjczycy mówili wyłącznie w jidysz - przekładał się nie tylko na budowę osobnych miejsc kultu: ubodzy przybysze z Niemiec i Rzeczypospolitej Obojga Narodów gnieździli się w stołecznym east endzie, tworząc ,proletariacką" subkulturę, w której ważną rolę w budowie podstawowych więzi odgrywały związki na pograniczu prawa, tworzone przez złodziei i paserów. Kariery Sefardyjczyków rozgrywały się na innym piętrze społecznych relacji: Abraham Ricardo (ojciec Dawida) i Moses Mendes byli zamożnymi maklerami, Izaak Schomberg znanym lekarzem (zajmował się dolegliwościami reżysera Dawida Garricka), a S. Gideon, Jacob Ray (John King) i J. Salvador obracali się w sferach zamożnej finansjery, świadcząc usługi (pożyczki) szlacheckiej elicie. Mimo niewielkiej liczby Żydzi byli w Londynie jedną z tych grup etnicznych, wobec których angielska, protestancka ulica łatwo umiała się „zdefiniować" za pomocą najprostszych mechanizmów - odrzucenia i agresji. W 1753 r. parlament - na wniosek sefardyjskiej elity - projektował umożliwić Żydom - nie wszystkim i za wysoką cenę - częściową naturalizację i dzięki temu uregulowanie ich prawnego statusu. Jew bill, przyjęty przez obie izby, a potem pod naciskiem ulicy odrzucony wywołał wybuch agresywnej antyżydowskiej propagandy. Gazeta „Evening Post” rozpętała histerię, odwołując się do wszystkich znanych już i „typowych" stereotypów. Opisywała m.in. wybuch niechęci wobec Żydów, którzy pojawili się w stołecznym teatrze. „Po drugiej uwerturze [second musick] zauważono żydowskich panów i panie na jednym z balkonów, natychmiast rozległ się okrzyk «Żadnych Żydów, precz z nimi, obrzezać ich [sic!]» itd. Po czym wielce niegrzecznie obrzucono ich gradem jabłek [--] do chwili, aż całe to towarzystwo nie zostało zmuszone do opuszczenia swoich

${ }^{19}$ M. Oron, Dr. Samuel Falk and the Eibenschuetz-Emden Controversy, w: Magic and Kabbalah in Askenazi Judaism. International Symposium held in Frankfurt a.M., 1991, red. K. Grozinger, J. Dan, Berlin-New York 1995, s. 242-256. O zjawisku ba'alei shem zob. G.D. Hundert, Jews in Poland Lithuania in the Eighteenth Century: A Genealogy of Modernity, Berkeley-Los Angeles 2004, s. 142-153. 
miejsc". Gazety przedrukowywały pełne zjadliwych komentarzy mowy parlamentarne wygłoszone przy okazji debaty nad ustawą oraz gorliwie informowały o wszelkich „europejskich” przypadkach, które mogły odpowiednio - negatywnie - ukierunkować nastroje opinii publicznej ${ }^{20}$.

${ }^{20}$ „After the second Musick some Jew Ladies and Gentlemen were noticed in one of the Balconies when a Cry immediately began «No Jews, out with them, circumcise them» [sic] etc.etc. and was followed with a Shower of Apples etc. with great Rudeness till the Company were obliged to leave their Seats, „Evening Post”, cyt. za M. Ragussis, Jews and Other „Outlandish Englishmen”: Ethnic Performance and the Invention of British Identity under the Georges, „Critical Inquiry” 26, 2000, 4, s. 773. Jeden z posłów (nie wymieniony z nazwiska, gdyż obowiązywał jeszcze zakaz cytowania w prasie nazwisk posłów, którzy przemawiali w Izbie Gmin) twierdził, że „we wszystkich krajach u źródła handlu stoi przemysł, ale żaden Żyd, nawet najbiedniejszy, nie urodził się do przemysłu ani rzemiosła, ani żadnego zajęcia związanego z pracą, nigdy więc w jakimkolwiek kraju nie zainicjują handlu. [--] W Polsce od wieków mieszkają całe rzesze Żydów, nikt jednak nie powie, że Polska to kraj handlu [--] w tym kraju, chociaż mieszkali tu [--] przez prawie 230 lat nie zajmowali się handlem, ale głównie lichwą. [--] a ponieważ rozrzuceni są po całym świecie i utrzymują ze sobą korespondencję, wiedzą, gdzie towary można sprzedać z największym zyskiem” („for the origin of trade in all countries is manufacture; but none of the Jews, even of the poorest sort, are ever bred to be manufacturers or mechanicks, or indeed to any laborious employment; therefore they can never be the beginners of trade in any country. [- - In Poland there have been multitudes of Jews for many ages, yet no man will say that Poland is a trading country. [--] In this country, tho' they were settled here [- - ] near 230 years, yet they never set up any trade, but dealt chiefly in usury, [--] and as they are dispersed over the whole world, and keep a correspondence with one another, they know where all sorts of manufactures may be sold to the best advantage”), ,The London Magazine" 22, 1753, s. 310 n. Ten sam miesięcznik podawał pod datą 11 czerwca 1753 r. depeszę (niemal reportaż) z Wilna, zapewne jako dowód z jednej strony katolickiej mściwości, a z drugiej żydowskiego uporu i fundamentalizmu (nie poddającego się asymilacji). „Mamy szokujący dowód zemsty papistów przeciw Żydowi: kilka dni temu sąd miejski wydał wyrok na apostatę, Rafaela Sentimany, z pochodzenie Chorwata, wykształconego w wierze chrześcijańskiej, który w wieku 12 lat wyrzekł się jej i przyjął judaizm oraz imię Abraham Isakowicz. W więzieniu odwiedzało go codziennie kilku gorliwych duchownych, wykazując mu ogrom zbrodni apostazji, namawiając do pokuty i powrotu na łono Kościoła. Przez dzień czy dwa mieli nadzieje, ale okazało się, że się mylili, ani bowiem nadchodząca tortura, ani propozycja wybaczenia nie wywierały na nim wrażenia. Dziewiątego zaprowadzono go na miejsce straceń: pod szubienicą kat wyrwał mu język i rzucił przed nim w ogień, potem związanego żywcem wrzucono między płonące bierwiona. Kiedy spłonął, popioły rozrzucono na wietrze. Biedny nieszczęśnik przyjął śmierć z determinacją, ani nie jęknął, ani przez chwilę nie okazał strachu” („From Wilna in Poland, June 11, we have an instance equally shocking of popish revenge against a Jew, as follows: The court of judicature in this city pronounced sentence a few days ago against an apostate, named Raphael Sentimany, a native of Croatia, who after being educated in the Christian religion, renounced it at the age of 12 years, embraced Judaism, and took the name of Abraham Isacowicz. While he was in prison, several zealous priests daily visited him, shewing him the heinousness of the crime of apostasy, and exhorting him to repent and return to the church; and for a day or two they had some hopes of reclaiming him: But 
Na poziomie ulicy agresja bywała codziennością. W kwietniu $1776 \mathrm{r}$. miesięcznik „The Gentleman's Magazine” informował, że pewna karczmarka w Westminster napadła Żyda i wysmarowała mu brodę wieprzowym tłuszczem, natomiast w portowym Portsmouth w $1781 \mathrm{r}$. do domu żydowskiej (aszkenazyjskiej) rodziny wrzucono martwą świnię. Żydów łatwo identyfikowano jako pośredników ekspansji kultury przestępczej. W czerwcu 1766 r. prasa informowała, że „Edward McGinnis i jego siostra Jane zostali powieszeni na Tyburn za kradzież zastawy znacznej wartości z domu pana Jamesa Adaira. Wieczorem po egzekucji wielka liczba ich irlandzkich rodaków zebrała się przed domem niejakiego Harta, Żyda, rozbiła wszystkie okna i wyrządziła inne szkody pod zarzutem, że był ich wspólnikiem i przyjął rzeczy zrabowane, ale naprawdę dlatego, że przyczynił się do ich skazania"21.

Napad w Chelsea trwał krótko. Po ucieczce bandytów pani Hutchins zobaczyła swego służącego Josepha Slewa, który ociekał krwią - starał się

they soon found themselves mistaken; he was so hardened, that neither the torments he was to suffer, nor the offer of a pardon, could make any impression on him. The 9th instant he was led to execution: Being arrived under the gallows, the executioner plucked out his tongue, and flung it into the fire before his face; and than, with his hands tied behind him, he was thrown alive into a heap of blazing faggots. When his body was consumed, the ashes were scattered in the wind. This poor wretch suffered death with great resolution; not so much as a groan, or the least sign of fear having escaped from him”), „The London Magazine” 22, 1753, s. 342. Por. A. M. Hyamson, The Jew Bill of 1753, "Transactions of the Jewish Historical Society of England" 6, 1912, s. 156-188; R. Liberles, The Jews and Their Bill: Jewish Motivations in the Controversy of 1753, "Jewish History" 2, 1987, 2, s. 29-36; D. Rabin, The Jew Bill of 1753: Masculinity, Virility, and the Nation, „Eighteenth-Century Studies” 39, 2006, 2, s. 157-171; T. M. Endelman, op. cit., s. 24-26, 30-33, 59-64.

${ }^{21}$ „Edward McGinnis and Jane his sister were executed at Tyburn, for stealing plate out of the house of James Adair, Esq; to a considerable amount. In the evening after the execution a great number of their Irish countrymen assembled before the house of one Hart, a Jew, broke all the windows, and did other damage, on pretence of his being an accessory, by receiving the goods they had stolen; but in fact for being a means of their conviction”, „The Gentleman's Magazine” 36, 1766, s. 293; ibidem 46, 1775, s. 189. Por. J. Warner, Violence Against and Amongst Jews in An Early Modern Town: Tolerance and its Limits in Portsmouth, 1718-1781, „Albion: A Quarterly Journal Concerned with British Studies” 35, 2003, s. 428-448 (zwł. s. 439); G. A. Cranfield, The „London Evening-Post” and the Jew Bill of 1753, ,The Historical Journal” 8, 1965, 1, s. 16-30; T. M. Endelman, The Checkered Career of "Jew” King: A Study in Anglo-Jewish Social History, „AJS [Association for Jewish Studies] Review" 7/8, 1962/1963, s. 69-100; I. S. Lustig, Boswell and the Descendants of Venerable Abraham, „Studies in English Literature, 1500-1900” 14, 1974, s. 435-448. Daniel Statt szacował, że w połowie XVIII w. w Londynie mieszkało ok. 7 tys. Żydów, zob. D. Statt, Foreigners and Englishmen: The Controversy over Immigration and Population, 1660-1760, Newark, Del. 1995, s. 30. Por. M. A. Shulvass, From East to West: The Westward Migration of Jews from Eastern Europe during the Seventeenth and Eighteenth Centuries, Detroit 1971. 
on zejść ze schodów w okrwawionej koszuli, aż padł nieruchomo. Pierwotna relacja prasowa mówiła, że dostał kulę w głowę - i walczy ze śmiercią - wdowa zaś twierdziła, że postrzelono go w plecy tak, że kula wyszła na wylot i zapaliła nocną koszule, którą starała się zgasić. O krwawych wydarzeniach, do których doszło na piętrze domu, najwięcej miał do powiedzenia John Stone, drugi ze służących. Zeznał, że na górę wdarło się pięciu mężczyzn, którzy obudzili go lufą pistoletu, krzycząc „zamknij oczy skurwysynu, leż, albo ci rozwalimy łeb". Obudzili też jego kolegę Josepha Slewa - a kiedy ten przestraszony wyskoczył z łóżka, wpakowali mu kulę w plecy (jednak nie w głowę!) i wywlekli ciało na schody. Stone zachował przytomność umysłu: wyskoczył przez okno (albo trap-door), skrył się w rynsztoku (gutter) i mimo że strzelano do niego, ukrywał się przez dziesięć minut, aż zobaczył, jak bandyci opuszczają dom. Na sali sądowej zeznania Stone'a miały duże znaczenie: kiedy poproszono go o rozpoznanie napastników z sypialni, podszedł do podsądnych i palcem wskazał L. Weila, H. Lazarusa i S. Portera ${ }^{22}$.

${ }^{22}$ Według jego zeznania: „D-n [= damn] your eyes you son of the bitch if you speak another word I will blow your brains out”, OBSP. Wg „The London Magazine” 40,1771, s. 618 dodatkowo padły słowa „lie still, (or we’ll blow your brains out)”. Między zeznaniami świadków a pierwotną relacją prasową zachodziły pewne różnice. Doniesienie o napadzie opublikowane $\mathrm{w}$ „The Oxford Magazine” pod datą 14 czerwca brzmiało: „We wtorek wieczorem ośmiu bandytów [ruffians] włamało się do domu pani Hutchins, właścicielki gospodarstwa rolnego przy King’s Road, w Chelsea. Rodzina złożona była z niej, trojga dzieci, z których najstarsze nie miało 3 lat, dwóch służących i dwóch pokojówek. Bandyci po wejściu do domu udali się do sypialni pani Hutchins, przyłożyli jej pistolet [ty? - P.T.D.] z obu stron głowy i zażądali kluczy. Dwóch zostało na czatach, a reszta rozeszła się po domu. Związali razem od głowy po nogi dwie służące. Jeden ze sług usłyszał hałas, zszedł po schodach, strzelili do niego niecelnie i uciekł przez zapasowe drzwi [trap-door], drugiego znaleźli w łóżku, a kiedy spytał, czego chcą, jeden z nich strzelił mu w głowę. Otworzyli schowek [bureau] i zabrali ponad 80 funtów w gotówce i banknoty, zabrali także zastawę znacznej wartości, a z innych pokojów pościel. Uciekli, a ranny jest teraz bliski śmierci” („On Tuesday night eight ruffians broke into the house of Mrs. Hutchins, farmer, in the King's-road, Chelsea; the family consisted of herself, three children, the eldest not three years of age, two man servants, and two maids; as soon as the villains had entered the house, they went to the bedside of Mrs. Hutchins, clapped a pistol to each side of her head, and demanded her keys, [--], two remained as a guard, and the rest went to other parts of the house, when they tied the two maids neck and heels together; one of the men servants hearing a noise, came on the staircase, at whom they fired, but missed him, and he made his escape through a trap-door; the other man they found in his bed, and on his asking what they wanted, one of them fired, and shot him in the head. They opened the bureau, from whence they took upwards of $80 £$ in cash, besides notes; stripping it likewise of plate to a considerable value, and the other rooms of linen etc. with which they got off. The wounded man now lies at the point of death”), ,The Oxford Magazine" 1771, 6, s. 230. Obaj służący spali na piętrze, co przystaje do innych znanych przypadków lokalizacji pomieszczeń dla służby. Por. B. Heller, op. cit., s. 633. 
Wdowa Hutchins, podobnie jak większość ofiar londyńskich przestępstw XVIII w., które znamy z opisów procesów oraz z prasy, pozostaje postacią enigmatyczną. Była właścicielką domu i gospodarstwa rolnego położonego przy głównym trakcie (King's Road) w Chelsea. W podstołecznej wiosce zamieszkałej zarówno przez bogatych, jak i borykających się z problemami ubóstwa należała zapewne do kategorii określanej przez historyków terminem „middle sort”, warstwy średniozamożnej ${ }^{23}$. Matka trojga małych dzieci, posiadała dwóch służących, posługaczkę i kucharkę: obsługę liczną i świadczącą o jej finansowych możliwościach. Nie wiemy, w jaki sposób wzorem innych owdowiałych Angielek dysponowała swoimi dochodami i oszczędnościami. Wdowy - w przeciwieństwie do mężatek, podporządkowanych władzy mężczyzn - mogły bez utrudnień prowadzić interesy, otwierać własne rachunki bankowe, zajmować się działalnością handlową. Hutchins twierdziła, że bandyci zabrali jej 61 gwinei ( 1 gwinea = funt i 1 szyling, a pierwsza informacja mówiła nawet o 80 funtach). Była to znaczna kwota, nie wiadomo, czy oszczędności całego życia, czy tylko gotówka, którą - nierozważnie trzymała w domu. Pobieżny przegląd spraw, w których ofiarami były kobiety, wskazuje, że w wielu przypadkach złodzieje potrafili się dobrze obłowić. Skazany na śmierć w maju 1771 r. Robert Connor włamał się do mieszkania Elisabeth Chancellor na Duke Street (w prestiżowej dzielnicy St. James, blisko pałacu królewskiego) i zagarnął pieniądze i przedmioty o wartości 204 funtów ${ }^{24}$.

Napastnicy byli rozczarowani zawartością szaf: szukali sreber, choć miejsce zamieszkania pani Hutchins mogłoby skłaniać raczej do poszukiwania wzorowanej na drezdeńskiej i sewrskiej rodzimej porcelany. Miejscowa manufaktura mogła poszczycić się zastawą, którą Jerzy III podarował w 1763 r. księciu meklemburskiemu. W 1770 r. fabrykę nabył nowy inwestor, bankier William Duesbury, właściciel dobrze prosperującej manufaktury w Derby ${ }^{25}$.

${ }^{23} \mathrm{Na}$ temat rosnącej liczby ubogich w Chelsea (w $1737 \mathrm{r}$. powstały parafialne warsztaty dla biedoty) zob. Chelsea Settlement and Bastardy Examinations, 1733-1766, red. T. Hitchcock, J. Black, London 1999. Użyteczny wstęp na temat (trwającej) debaty nad strukturą społeczną osiemnastowiecznej Anglii przedstawił Henry R. French, The Search for the "Middle Sort of People” in England, 1600-1800, „The Historical Journal” 43, 2000,1 , s. 277-293.

${ }^{24}$ „The Gentleman's Magazine” 41, 1771, s. 235. Dla określenia mieszkańców wspólnej przestrzeni domowej, zarówno powiązanych więzami krwi, jak i lokatorów i służby, historiografia brytyjska używa terminu „household family”, zob. N. Tadmor, The Concept of the Household-Family in Eighteenth-Century England, „Past \& Present” 1996, 151, s. 111-140.

${ }^{25}$ A. Esdalie, Some Eighteenth-Century Literary Allusions to Chelsea China, „The Bur- 
Jak pisał Peter King, opisując głównych aktorów osiemnastowiecznego angielskiego procesu karnego, głównym „decydentem”, który w dużej mierze wpływał na akt oskarżenia i na przebieg sprawy, była sama ofiara ${ }^{26}$. Zeznania pani Hutchins koncentrowały się na opisie napadu, zachowaniu bandytów oraz na stratach, które poniosła. Zapytana, co zginęło z jej domu, Hutchins wspomniała - poza zegarkiem i pieniędzmi tylko jeden przedmiot: sztukę (piece) jedwabiu cytrynowej barwy. Nie chodzi nawet o to, że - jak się okaże - wdowę zawiodła pamięć. W kontekście wyników badań nad inwentarzami ruchomości można raczej zapytać, czego z jej domu nie ukradziono. Ustalając katalog przedmiotów, które określały poziomy zamożności angielskich kobiet (w latach 16751725), Lorna Weatherill wymieniała m.in. zegary, srebrną zastawę, porcelanę (raczej rodzimą niż bardzo drogą importowaną), książki, obrazy i ryciny. Średnia wartość przedmiotów domowego użytku posiadanych przez kobiety z londyńskiego (uboższego) East Endu wynosiła zaledwie 28 funtów (a wartość całkowita - 121 funtów), jednakże $27 \%$ z nich posiadało zegary, $78 \%$ lustra, $77 \%$ obrusy stołowe, $13 \%$ porcelanę, a $55 \%$ przedmioty ze srebra. Na tym tle wartość strat wdowy Hutchins plasowała ją wysoko, ale powodem była przede wszystkim skradziona kwota pieniędzy. Choć wiemy o zegarku, Hutchins nic nie wspominała o pozostałych wyznacznikach statusu majątkowego. Złodzieje - pomimo że wzmianki z pierwszego raportu o włamaniu wskazywały większe łupy (,srebrna zastawa znacznej wartości”) - albo ich nie znaleźli, albo nie mieli dostatecznie dużo czasu na poszukiwania, lub też, w co już trudniej uwierzyć, nie chcieli ich zabrać (można też przypuścić, że prasa wyolbrzymiała poniesione przez nią szkody) ${ }^{27}$.

Wdowę Hutchins stać było na zakup jedwabiu, zarówno produkowanego przez rodzimych rzemieślników, jak importowanych indyjskich tekstyliów najwyższej jakości ${ }^{28}$. Materiał, który wpadł w ręce złodziei,

lington Magazine for Connoisseurs" 46, 1925, 262, s. 9. Por. H. Young, Manufacturing Outside the Capital: The British Porcelain Factories, Their Sales Networks and Their Artists, 1745-1795, „Journal of Design History” 12, 1999, 3, s. 257-269.

${ }^{26}$ Zob. P. King, Decision-Makers and Decision-Making in the English Criminal Law, 17501800, ,The Historical Journal” 27,1984, 1, s. 27. W rozprawie uczestniczyli też adwokaci oskarżenia i obrony (po dwóch), ,"The Oxford Magazine” 1771, 7, s. 225.

${ }^{27}$ L. Weatherill, A Possession of One's Own: Women and Consumer Behavior in England, 1660-1740, ,Journal of British Studies” 25, 1986, 2, s. 131-156. Por. B. Todd, Remarrying Widow: A Stereotype Reconsidered, w: Women in English Society, 1500-1800, red. M. Prior, London-New York 1985, s. 54-92.

${ }^{28}$ Na początku XVIII w. w Chelsea osiedliło się wielu hugenotów, tkaczy jedwabiu (chałupników), którzy emigrowali z Francji, jednakże po 1750 r. mimo występujących jeszcze obco brzmiących nazwisk produkcja upadła. We wschodnim Londynie (Spitalfields) nadal mieszkało bardzo wielu tkaczy, surowiec sprowadzano początkowo 
był zapewne przeznaczony na suknie. Jedwab okazał się jednak nie tylko najważniejszym materialnym dowodem w sprawie, ale - jak będę dowodzić - stanowił pewną nić, która w więcej niż tylko symboliczny sposób łączyła zbiorową wyobraźnię wspólną dla sędziów, świadków i oskarżonych. Nie bez powodu tytułowa bohaterka „kryminalnej” powieści Daniela Defoe, złodziejka nazywana w środowisku przestępców Moll Flanders, trafia do transportu deportowanych za Ocean skazańców za kradzież sztuki jedwabiu. Świadek Solomon Lazarus, w jednej z relacji prasowych określony jako właściciel lombardu (pawnbroker) przy Goodman’s Fields, zeznał, że „Asher i Levi Weil zostawili u niego sztukę [piece] cytrynowego jedwabiu i kilka półmisków, ale potem, kiedy dowiedział się, że pisze się o tych przedmiotach w gazecie, poszedł do obu Weilów, którzy przyznali, że mają je od pani Hutchins z Chelsea"29.

Napastnicy wykazali się zawodowstwem. Dokonali gruntownego rozpoznania. Na sześć tygodni przed napadem H. Lazarus zaszedł na farmę. Podawał się za tkacza i zadał pani Hutchins pytanie o osobę, której nie znała. Świadek William Wood, były sierżant, karczmarz z Chelsea, zeznał, że na dwa miesiące przed włamaniem do domu pani Hutchins do jego oberży (ale house) weszło na kufel piwa dwóch mężczyzn, jeden wysoki, a drugi niski. Przytoczył pytania, które mu zadawali: kto mieszka na farmie blisko oberży, czy mieszkają tam lokatorzy, ilu mężczyzn i jakie kobiety. Wood wyjaśnił, że mieszka tam pewna wdowa, na co przybysze od-

z Włoch (ale po 1739 r. Wiktor Amadeusz II zakazał eksportu surowca), potem z Lewantu (Turcji i Persji), ale konkurencja francuskiej kontrabandy oraz wysokiej jakości modnych jedwabiów z Indii oraz z Chin powodowała, że - mimo protekcjonistycznych barier - londyńscy tkacze (także kobiety i dzieci) często (np. w 1763, 1764 i 1769 r.) wszczynali w Londynie wielotysięczne (w 1769 r. - 2000 osób) rozruchy, sprzeciwiając się obcej konkurencji. Zob. G. B. Hertz, The English Silk Industry in the Eighteenth Century, „The English Historical Review” 24, 1909, 96, s. 710-727. Wyroby z jedwabiu stanowiły wyznacznik zamożności, tym ważniejszy, im dalej od „centrów cywilizacji": spis ruchomości Williama Pengree, właściciela plantacji na Florydzie (i 63 niewolników), wymieniał „jedwabną kamizelkę i pończochy”, zob. S.R. Parker, Men Without God or King: Rural Settlers of East Florida, 1784-1790, „The Florida Historical Quarterly" 69, 1990,2, s. 146.

${ }^{29}$ „Solomon Lazarus, a pawnbroker near Goodman's Fields deposed that about the middle of June last Asher and Levi Weil pawned with him a lemon-coloured piece of silk, several pieces of plate etc. but afterwards he seeing those goods advertised he went to the said two Weils who acknowledged they got it at Mrs. Hutchins's at Chelsea”, „The London Magazine” 40, 1771, s. 618. Por. L. A. Chaber, Matriarchal Mirror: Women and Capital in Moll Flanders, „PMLA [Publications of the Modern Language Association of America]" 97, 1982, 2, s. 212-226; G. Hentzi, Holes in the Heart: Moll Flanders, Roxana, and „Agreeable Crime”, ,boundary 2" 18, 1991, 1, s. 174-200; S. C. Michael, Thinking Parables: What Moll Flanders Does Not Say, „ELH [English Literary History]” 63, 1996, 2, s. 367-395. 
parli, że widzieli ją i że jest bardzo ładną kobietą. Po pół godzinie Wood wysłał sąsiadce wiadomość o tej rozmowie, ale w sądzie - ze względu na „swoje ułomności” nie potrafił rozpoznać, którzy z oskarżonych złożyli mu wizytę. Bardziej obciążające było zeznanie świadka Daniela Isaacsa, który „mówił po niemiecku [high Dutch] i tłumaczył go pan Myers, gwardian synagogi. Zeznał pod przysięgą, że zna oskarżonych, że wciągnęli go do bandy [gang], a jej herszt [captain] Asher Weil przysiągł, że potnie go na szmaty [thongs], jeśli ich zdradzi. Wiedział o planowanym napadzie na panią Hutchins i miał brać w nim udział, a Asher Weil mówił, że mają iść do Chelsea i włamać się do domów pewnego pana [lord] i jednej wdowy i że tej nocy obłowią się na ponad 40000 funtów, ale ponieważ się rozchorował, żona nie pozwoliła mu iść". Zeznanie Isaacsa nie tylko rysowało horyzont oczekiwań rabusiów, ale wyraźnie wskazywało na istnienie zorganizowanej bandy, która planowała napady. Świadek pośrednio przyznawał się do współudziału w obrocie kradzionymi przedmiotami i opisywał spotkania (przy kuflu piwa) z członkami gangu.Jego zeznanie stanowiło dla podsądnych zagrożenie i jeden z nich - H. Lazarus - usiłował go zdyskredytować, twierdząc, że „nie wie, czy należy go zaprzysięgać, ponieważ już kilka razy zmieniał się z chrześcijanina w Żyda" ${ }^{30}$.

Wyjaśnienia, w jaki sposób stołeczny aparat sprawiedliwości wpadł na trop bandytów, udzielił świadek S. Lazarus, którego zeznanie niosło śmiertelną - w sensie dosłownym - groźbę dla oskarżonych ${ }^{31}$. Znał ich od dawna i zdecydował się powiadomić najpierw parnasa synagogi, Myersa, a potem sir Johna Fieldinga o ważnych dowodach, którymi dysponował. Zapewne wówczas zdecydował się na współpracę, zamiast fence (pojęciem tym współczesna anglojęzyczna socjologia określa współpracującego ze

${ }^{30}$ „Daniel Isaacs gave his evidence in High Dutch and was interpreted by Mr. Myers warden of the Synagogue [--] he swore that he had been for some time acquainted with the prisoners at the bar, that they enlisted him into their gang the captain, as he stiled Asher Weil swearing that he would cut him into thongs if he betrayed them, that he knew of the intended robbery at Mrs. Hutchins's and was to have been at the party, Asher Weil declaring that they were to go to Chelsea to break the house of a Lord and a Widow and that the night's exploit would be worth better than $£ 40000$ to them, but that he was sick and his wife would not let him go”, „Town \& Country Magazine” 3, 1771, s. 652, 654. W OBSP Isaacs potwierdził nieznajomość angielskiego. Zeznanie i obiekcje Lazarusa, ibidem, s. 11-12 (m.in. „he has turned from Christian to Jew several times").

${ }^{31}$ Przypadki wyroków skazujących za morderstwo stanowią - jak dowodził P. King - margines brytyjskiego orzecznictwa. W okresie 1791-1805 r. o morderstwo oskarżono w Londynie tylko 117 osób (przeważnie imigrantów), a stołeczne dane dotyczące skazanych za to przestępstwo z lat 1780-1794 wskazują, że w 70\% sprawcami i ofiarami byli mężczyźni, a w 40\% przyczyną były bójki, zob. P. King, The Impact of Urbanization, s. 691, 693-694, 696. 
złodziejami pasera i jego zajęcie) i wziął na siebie rolę „koronnego” świadka oskarżenia ${ }^{32}$. Nienowy dylemat i przeciwstawienie sprzecznych wizerunków: „uczciwego obywatela” czy potępionego przez swoich „kapusia" Lazarus rozstrzygał w duchu potrzeby zachowania godności i zapewnienia ochrony swojej grupie etnicznej. Decyzja zapadła ,jak tylko się dowiedziałem, że Synagoga, pan Myers i najważniejsi Żydzi są zdeterminowani, aby zbadać tę sprawę i w konsekwencji otrzymałem bilecik pana Fieldinga [pokazał go w sądzie - P.T.D.], który zachęcał mnie, abym przedstawił dowody [--] powodem, dla którego nie poinformował o tym wcześniej, były skrupuły sumienia, że odkrycie to wywoła wielki hałas i wzburzy naród" ${ }^{33}$. Wypowiedź ta potwierdza także, że starszyzna

32 OBSP. Por. N. Shover, Structures and Careers in Burglary, „, The Journal of Criminal Law, Criminology, and Police Science" 63, 1972, 4, s. 544-545.

33 ,that he had sent sir John Fielding word that important evidence he could give against them as soon as he heard that the Synagogue, Mr. Myers and the principal Jews were determined to probe the matter that in consequence he received a card from Sir John Fielding [--] encouraging him to become an evidence and that the reason he did not long since give an information of the affair arose from the scruples of conscience whether a discovery would not make a great noise and disturbance in the nation”, „Town \& Country Magazine” 3, 1771, s. 652. Wg protokołu zeznań w OBSP Lazarus powiedział m.in. „I was afraid it would make a great noise in the nation but when Mr. Myers and several other worthy gentlemen were determined to find out these people I sent to sir John Fielding and told him I would make a voluntary discovery if he would admit me an evidence" (w zapisanym zeznaniu brak odniesienia do „skrupułów sumienia”). Nieco inną - nie do końca potwierdzoną w zeznaniach wersję „konwersji pasera”, opublikowaną już w listopadzie 1771 r., przedstawiał „The Scots Magazine”: „pewien Żyd, który mieszkał przy Shoemaker Row na Aldgate, rozchorował się i skruszony, w obawie przed śmiercią posłał po przyjaciela, któremu wyznał, że jest jednym z dziewięciu Żydów zamieszanych w napad i morderstwo u pani Hutchins w Chelsea kilka miesięcy przedtem. Prosił, aby doniósł o tym urzędnikowi, podał ich nazwiska i adresy. Przyjaciel ów udał się zaraz do sir Johna Fieldinga, który wysłał swoich ludzi i czterech zatrzymano, przesłuchano i uwięziono [--] Żyd, który doniósł, zwrócił się do pana Myersa o zapomogę [--] pan Myers naradził się z sir Johnem Fieldingiem, który zdecydował, aby tamtego zatrzymać. [Myers] próbował wraz z rabinem skłonić go do złożenia zeznania. Człek ten powiedział tylko, że boi się, iż kilka osób, które teraz żyją w dostatku, popadnie niedługo w nędzę. Tajemnicze słowa spowodowały, że pan Myers i rabin, za pomocą gróźb i obietnic, skłonili informatora, aby udał się do sir Johna Fieldinga, który wnet wydobył prawdę” (,a Jew who lives in Shoemaker-row, Aldgate, being taken ill, and touched with remorse of conscience, (imagining he should die), [--] and acknowledged himself to be one of the nine Jews concerned in the robbery and murder at Mrs. Hutchins's in Chelsea, a few months ago. He desired his friend to inform some magistrate of the above; and having told him the names and places of abode of his accomplices, his friend went immediately to Sir John Fielding; who sent out his people after them, by which means four of the gang were taken [- - ]. The Jew that turned evidence, being reduced to great want, applied to Mr. Myers, warden of a synagogue, for relief. [--] Mr. Myers in the mean while consulted Sir John Fielding, who advised that the man should be taken into custo- 
kahału postanowiła współpracować z organami sprawiedliwości, obawiając się zapewne, że sprawa oskarżenia o morderstwo doprowadzi do ulicznych rozruchów skierowanych przeciwko Żydom. Aby odgrodzić się od podejrzanych w synagodze, rzucono klątwę na wszystkich wspólników zamieszanych we włamanie ${ }^{34}$. Pojawiające się między wierszami wielu zeznań odwołania do osoby sir Johna Fieldinga, sędziego pokoju i administratora aresztu śledczego z ulicy Bow, kierownika półprywatnej agencji detektywistycznej, którą założył wraz z przyrodnim bratem, znanym pisarzem H. Fieldingiem, wskazuje, że jego osławieni „gońcy” (runners) szukali już wcześniej sprawców napadu i skorzystali zapewne z donosu Lazarusa. Praktyką agencji było publikowanie w codziennej prasie wykazu przedmiotów skradzionych (niechętni uważali, że „gońcy” sami czerpali korzyści z ich pokątnej sprzedaży), co wraz z dobrą penetracją kryminogennych środowisk oraz „nowoczesnymi”, wnikliwymi - publicznymi, niemal „teatralnymi” - metodami przesłuchań podejrzanych przynosiło Fieldingom nie tylko renomę i "sławę”, ale uczyniło z nich postrach przestępców ${ }^{35}$. Dzięki takim metodom najpewniej wpadli na ślad „doktora”, zatrzymali go i podali sprawę do publicznej wiadomości. Sprowadzona przez L. Weila młoda dziewczyna, która miała zapewnić mu alibi, wyznała, że „choć często czytała gazety, nie słyszała, aby [doktor] był tam [u Fieldinga] przesłuchiwany". Służący J. Stone także przyznał, że przed rozprawą przesłuchiwał go już Fielding, przygotowując jak to było w jego zwyczaju - dokumentację dla królewskiego sądu. Relacja Lazarusa miała kluczowe znaczenie dla losu podsądnych. Przed sądem zeznawał, że „dzień lub dwa po napadzie w Chelsea Asher Weil i jego brat doktor spotkali go i mieli [ze sobą] tobołek z chusty. Wrócił z nimi do domu, poprosili, by wszedł na górę, gdzie wyjęli sztukę cytrynowego jedwabiu, na 15 i pół jarda, a doktor wyjął z kieszeni złoty zegarek w zielonej skórkowanej [dog skin] oprawce i stalowy łańcuszek, kilka łyżek stołowych i do herbaty, kufel i trochę innych rzeczy ze srebra.

dy. Myers chose to act with honour and tried, in conjunction with a Rabbi, to bring the man to confession. The fellow would go no farther than declaring that he was afraid several people who now lived in prosperity, would ere long be miserable. These mysterious words alarmed Mr. Myers and the Rabbi, and with threats and promises they prevailed on the informer to go before Sir John Fielding, who soon brought him to a discovery”), ,The Scots Magazine” 33, 1771, s. 700-701. Zeznanie Lazarusa w OBSP.

${ }^{34}$ „An anathema was pronounced at the synagogue in Duke's Place, against all the accomplices in the late robbery at Mrs. Hutchins's”, „The Gentleman's Magazine” 41, 1771, s. 566.

${ }^{35}$ Przykład krytyki metod postępowania J. Fieldinga zob. W. R. Irwin, An Attack on John Fielding, „Modern Language Notes” 56, 1941, 7, s. 523-525. Por. J. M. Beattie, Sir John Fielding and Public Justice. 
Kupił wszystko za 14 funtów [- - ] w kilka dni później doktor, Hyam Lazarus i Solomon Nineveh [nadal nie schwytany - wpisano w protokole P.T.D.] przyszli do niego i rozmawiali o sprawie w Chelsea. Doktor powiedział: «Nineveh zastrzelił człowieka», a ten odparł «jak to może być, skoro wiesz, że stałem na czatach i ty go zastrzeliłeś», na co doktor przyznał się i jeszcze powiedział, że laską ogłuszył psa, a potem go zastrzelił. Hyam Lazarus skarżył mu się wtedy, że nie dostał wszystkich pieniędzy i otrzymał tylko 5 funtów i 5 szylingów z tego włamania"36.

Sprawę napadu i mordu w Chelsea potraktowano bardzo poważnie. Trybunał przy Old Bailey zbierał się zwyczajowo raz w miesiącu, aby „hurtowo" rozpatrywać zgromadzone dowody oraz za pomocą szybko wydawanych wyroków „opróżnić więzienie”. W czasie sesji w ostatnim tygodniu lutego $1771 \mathrm{r}$. wydano m.in. 9 wyroków śmierci, 68 wyroków deportacji, przeważnie na najniższy okres 7 lat (za drobne kradzieże, np. Elizabeth Farmer za kradzież „dziecięcej sukienki”), 8 wyroków skazujących na wypalenie znamienia na dłoni oraz 7 skazujących na karę chłosty. Surowa praktyka trybunału była powszechnie znana i oskarżeni w sprawie z Chelsea mogli już wcześniej wiedzieć, jaki wyrok ogłoszono po procesie pary włamywaczy, którzy z domu przy Park street ukradli zastawę stołową wartą 1000 funtów, oraz znać sentencję ogłoszoną w sprawie ich wspólników - paserów (jeden nazywał się Jacob Jacobus i był zapewne członkiem żydowskiej diaspory), których potraktowano łagodniej i skazano na czternastoletnią deportację ${ }^{37}$. W czasie

36 ,in a day or two after the robbery at Chelsea, Asher Weil, and his brother the Doctor, met him with a bundle tied in a handkerchief, and desired him to return to his house with them. When they came there they begged him to go up stairs, where they took out of the handkerchief a piece of lemon coloured silk, about fifteen yards and a quarter, the Doctor took alto out of his pocket a gold watch with a green dog-skin outer case, and a steel chain, some table and tea spoons, a mug, and some other silver things, all which Solomon Lazarus bought for $14 £[--]$ that in a few days afterwards, the Doctor, Hyam Lazarus, and Solomon Nineveh (not yet taken) called on him, and talking of the Chelsea affair, the Doctor said, Nineveh shot the man, when Nineveh replied, «How could that be, when you know I stood centry, and you shot him»; which the Doctor confessed, and allowed that he knocked down the dog with his stick, and then shot him; Hyam Lazarus at this time complained to Solomon that some of the money was kept back, for that he had received only $5 £ .5 \mathrm{~s}$. on account out of the robbery”, „Town \& Country Magazine” 3, 1771, s. 652-653. Przekręcone w gazetach nazwisko „Nineveh” dotyczyło - wedle protokołu zeznań - Abrahama Lineville’a (sądząc z nazwiska, pochodził z Lotaryngii), uczestnika napadu, którego do dnia procesu nie schwytano.

${ }^{37}$ Sesję z lutego 1771 r. relacjonował m.in. „The Gentleman's Magazine” 41, 1771, s. 93, 137-138. Niekiedy prasa ograniczała się tylko do przedstawienia statystyk, bez podawania nazwisk i kwalifikacji czynów: w sesji majowej 1770 r. naliczono 130 (anonimowych) podsądnych, którym zasądzono 30 wyroków śmierci, 46 deportacji (w tym 
kolejnej, trzydniowej sesji w kwietniu osądzono 17 osób: zapadły 4 wyroki śmierci, 7 wyroków deportacji, 2 napiętnowania rozpalonym żelazem, a 9 osób uniewinniono ${ }^{38}$. W lipcu 1771 r. sesja trwała 5 dni, a jej wyniki relacjonowane w prasie - przedstawić można w następujący sposób:

\begin{tabular}{|c|c|c|c|c|c|c|}
\hline 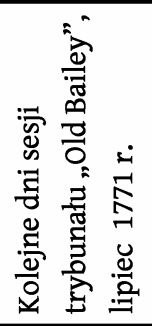 & 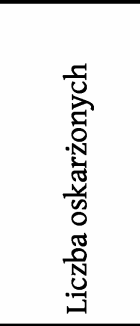 & 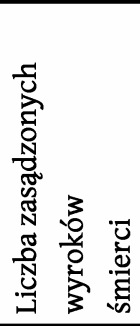 & 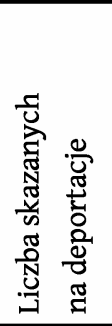 & 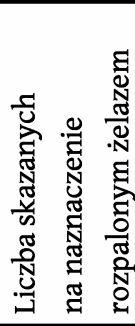 & 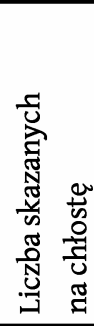 & 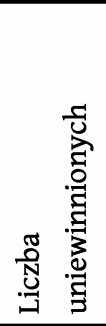 \\
\hline 3 lipca & 21 & 3 & 9 & - & 1 & 10 \\
\hline 4 lipca & 19 & 3 & 9 & 1 & - & 6 \\
\hline 5 lipca & 15 & 1 & 7 & - & - & 1 \\
\hline 8 lipca & 19 & - & 4 & - & 1 & 14 \\
\hline 9 lipca & 23 & 3 & 8 & - & - & 12 \\
\hline Razem (\%) & 97 (100\%) & $10,3 \%$ & $38,1 \%$ & $1 \%$ & $2 \%$ & $44,3 \%$ \\
\hline
\end{tabular}

Źródło: „The Gentleman’s Magazine” 41,1771, s. 330-332.

Oskarżenie przeciwko żydowskiej bandzie potraktowano z większą uwagą, poświęcając rozprawie niemal cały dzień. Zwykle trybunał był bardziej „wydajny”: 15 maja 1771 r. osądzono 24 osoby (3 wyroki śmierci, 8 deportacji), dzień później - 23 (15 deportacji), w dwa kolejne dni 8 (aż 5 wyroków śmierci) i 17 (2 wyroki śmierci i 6 deportacji), wreszcie 20 maja osądzono 28 osób (wydano 2 wyroki śmierci, 10 deportacji) ${ }^{39}$. Nie chodziło

jedna na 14 lat, a pozostałe na 7), 4 wyroki batożenia i 3 naznaczenia żelazem, w miesiąc później: na 83 podsądnych 13 skazano na karę śmierci, 27 na deportację (w tym 3 osoby na 14 lat), 4 na chłostę, a 2 na naznaczenie żelazem, zob. „Universal Magazine” 1770,46 , s. 273,330 . Na temat proliferacji osiemnastowiecznych ustaw grożących karą śmierci za popełnione przestępstwa zob. m.in. D. Hay, op. cit., s. 50 n.

38 „The Gentleman's Magazine”, 41, 1771, s. 189. Na temat deportacji (wyroki na 7, 14 lat oraz dożywotnio; przedterminowy powrót karano śmiercią, w latach 1767-1771 uciekło 14\%, przede wszystkim młodych mężczyzn, w okresie 1728-1796 kobiety stanowiły 9,6\% wśród uciekinierów) i deportowanych do Ameryki angielskich przestępców (w okresie 1718-1775 ok. 50 tys.) zob. F. Grubb, The Transatlantic Market for British Convict Labor, „The Journal of Economic History” 60, 2000, 1, s. 94-122, oraz idem, The Market Evaluation of Criminality: Evidence from the Auction of British Convict labor in America, 1767-1775, „The American Economic Review” 91, 2001, 1, s. 295-304.

${ }^{39}$ „The Gentleman's Magazine” 41, 1771, 235-236. W 1769 r. Samuel Johnson stwierdził, że „[Amerykanie] to rasa skazańców i powinni być nam wdzięczni za wszystko, na co im pozwalamy, prócz stryczka", za: F. Grubb, The Market Evaluation of 
zapewne o kwalifikacje czynu - trybunał spotykał się z podobnymi sprawami regularnie - ile o liczbę oskarżonych, trudności językowe i upór podsądnych. Sprawy o zbiorowe napady, szczególnie przestępstwa popełnione przez zorganizowane bandy, nie trafiały się aż tak często, choć gang żydowski - pod tym przynajmniej względem - nie stanowił aż tak znaczącego ewenementu, biorąc pod uwagę bandy drogowych rabusiów, a nawet kilkuosobowe, raczej skrzykujące się doraźnie na jedną „robotę” miejskie szajki (associations), które wpadały w ręce organów sprawiedliwości. W lipcu 1771 r. sądzono - i skazano na śmierć - Jamesa Saytfusa, alias Jeremiasza Niemowę (Dumb Jeremy), który wraz z dwiema wspólniczkami włamał się do domu przy Queen Anne’s street (Marylebone) i ukradł „dwa srebrne lichtarze". Czy podobnie jak gang Weilów była to szajka, której można przypisać dłuższą metrykę działalności, czy raczej grupa, której spójność zdefiniował jednorazowy cel - napad na dom w eleganckiej dzielnicy Marylebone, podobny do zaplanowanego włamania w podmiejskiej Chelsea? ${ }^{40}$ Londyńska przestępczość zorganizowana, szczególnie gangi złożone z przedstawicieli mniejszości etnicznej (np. Irlandczyków), nie została tak dobrze rozpoznana jak np. żydowskie podziemie kryminalne działające w XVIII w. w Niderlandach ${ }^{41}$. Zeznania złożone w procesie gangu

Criminality, s. 298. Na deportacje często skazywano rabusiów drogowych (50\% skazanych na okres czternastoletni), złodziei oraz (dożywotnio) kryminalistów, wobec których sądy żywiły dostateczną wątpliwość, aby nie skazać ich na powieszenie, ibidem, s. 298-299.

40 „The Gentleman's Magazine” 41, 1771, s. 331; „The Oxford Magazine” 1771, 7, s. 36. Doświadczenie sędziów w rozstrzyganiu spraw przeciw grupom przestępczym dotyczyło także (najczęściej miejskich) band kłusowników, którzy kradli dziczyznę w prywatnych (królewskich) lasach. W 1723 r. uchwalono ustawę (tzw. Black Act), która piętnowała kłusowanie nocą („,w przebraniu i z uczernionymi twarzami”), podwyższając wymiar kary (wcześniej grzywnę) do wyroku deportacji na 7 lat oraz dając możliwość wydawania także wyroków śmierci. Por. P. B. Munsche, Gentlemen and Poachers: The English Game Laws, 1671-1831, Cambridge 1981; J. Broad, Whigs and Deer-Stealers in Other Guises: A Return to the Origins of the Black Act, „Past \& Present” 1988, 119, s. 56-72.

${ }^{41} \mathrm{~F}$. Egmond, Crime in Context: Jewish Involvement in Organized Crime in the Dutch Republic, ,Jewish History” 4, 1989, 1, s. 75-100. Przestępcy grasujący na gościńcach bywali dobrze zorganizowani, por. „wczoraj [11 VI 1771 - nomen omen, data napadu w Chelsea - P.T.D.] o dziesiątej w nocy pewien szlachcic z żoną jechali powozem i zostali zatrzymani koło Peckham [dzielnica przedmieścia Southwark, na południowym brzegu Tamizy] przez pojedynczego łazika [footpad], który obrabował ich z zegarków, trzech gwinei i małej ilości srebra. Zachowywał się bardzo układnie i przekazał, że jeśli ktoś zaatakuje ich, zanim dojadą do miasta, mają wypowiedzieć słowa «oficer z Chelsea» [Chelsea Pensioner]. Niedługo potem przy trakcie zatrzymało ich dwóch łazików, a kiedy usłyszeli hasło, pozwolili im jechać dalej, nie nagabując ich” („Last night, about ten o'clock, a gentleman and his wife were stopped in their chaise near Peckham Gap, by a single footpad, who robbed them of their watches, three guineas, and some silver. The fellow behaved with great civility, and bid them, if they were attacked again 
Weilów nie pozwalają na zbyt daleko idące uogólnienia, ale rodzą pewne podejrzenia. Najbardziej "geograficznie” oddalona od miejsca przestępstwa gazeta, edynburski „The Scots Magazine”, jako jedyna zamieściła relację o wynikach wstępnego przesłuchania, któremu poddano czterech podejrzanych zatrzymanych przez ludzi Fieldinga. Okazywało się, że „banda ogromnie się rozrastała i sprowadzano nawet nowych zbirów z zagranicy, którzy snuli śmiałe i przewrotne plany [--]. Ustalono, że znaczna liczba Żydów uroczyście zawarła zmowę milczenia w celu poruszania się po kraju i okradania domów i mieli też posiadać na wybrzeżu statek, zawsze gotowy do drogi, aby wywozić łupy". Żaden inny przekaz nie potwierdza funkcjonowania aż takiego przedsiębiorstwa, jednak zatrzymanych oskarżono także o wcześniej (w lutym tr.) popełniony napad rabunkowy na dom innej kobiety, położony we wsi Wormley, o $25 \mathrm{~km}$ od stolicy, a A. Weil, broniąc się przed sądem, wymieniał Birmingham, gdzie jeździł handlować biżuterią (sądowi okazał kilka klejnotów, które wyjął z kieszeni) ${ }^{42}$. Paser Lazarus „,sypał" obficie i dokładnie: opisał komu i co sprzedał, relacjonował rozmowy o napadzie z braćmi Weil, w których uczestniczył, przyznał się do wieloletniego handlowania kradzionymi srebrami oraz udziału w napadzie na karetkę pocztową. Jego zeznania w znaczący sposób dopełniały obrazu wewnętrznej struktury całej szajki. Refleksja socjologiczna, przede wszystkim behawioralna koncepcja Edwina Sutherlanda dotycząca wymogu ,społecznego wsparcia", jakim cieszyła się złodziejska profesja, znajduje w przy-

before they got to town, to give the word «Chelsea Pensioner». Soon after two footpads stopped them near the turnpike, and, on receiving the pass word, suffered them to proceed without further molestation”), ,The Oxford Magazine” 1771, 6, s. 229.

42 „On the examinations it appeared that this gang was increasing to a dreadful degree; and that even fresh miscreants have been sent for from abroad, and arrived, and that they had formed some very daring and mischievous plans. [- - Than it was found, that a considerable body of Jews had entered into the most solemn engagements, not to betray one another, and to go about the country robbing and plundering houses; and that they were to have a vessel always ready upon the coast to export the plundered goods”. Gazeta ustalała także szersze kontakty gangu: „Levi Weil, Solomon Porter, Mark Asheburg, Hyam Lazarus, Lazarus Harry Asheburg oraz Asher Weil zostali oskarżeni o włamanie w lutym do domu pani Deighton w Wormley, w hrabstwie Hertfordshire, i kradzież pewnej liczby sreber [- - Ether Moses, alias Elias Jacobs, zwany też Polock [Polak?] został oskarżony o paserstwo [- - trzech z nich zatrzymano w Birmingham, a czwartego na trakcie do Birmingham, w karetce pocztowej, kiedy jechał ostrzec wspólników, żeby uciekali” („Levi Weil, Solomon Porter, Mark Asheburg, Hyam Lazarus, Lazarus Harry Asheburg, and Asher Weil, charged on the oath of an accomplice, with breaking open the house of Mrs. Deighton, in Wormley, in Hertfordshire in February last, and stealing a quantity of plate. [--] Esther Moses, and Elias Jacobs, otherwise Polock, charged with receiving part of the goods stolen [--]. Three of the last-named principal offenders were apprehended at Birmingham; a fourth was stopped on the road, as he was riding post to Birmingham to give his companions notice to escape”), „The Scots Magazine”33, 1771, s. 700-701. 
padku bandy Weilów wyraźne potwierdzenie ${ }^{43}$. Wszyscy $-\mathrm{z}$ wyjątkiem doktora - należeli do żydowskiego proletariatu, reprezentowali wspólnotę Aszkenazyjczyków, znacznie bardziej ekonomicznie i społecznie upośledzoną niż mniej liczna, bardziej wpływowa i bogata grupa sefardyjska. Z zeznań procesowych wynika, że tylko L. Weil umiał - z racji swojej profesji zapewnić sobie status powyżej poziomu ulicznej i kryminogennej biedoty. Jego były służący - Anglik - uważał go za ,uczciwego, ludzkiego człowieka, uważnie wykonującego swój zawód", w czasie wstępnego przesłuchania kucharka miała trudności z rozpoznaniem go, ponieważ „był dobrze ubrany i upudrowany", inni świadkowie wspominali, że leczył z powodzeniem także kobiety chrześcijanki. Weil przełamał barierę kulturowej izolacji, która uniemożliwiała większości Aszkenazyjczyków podjęcie zajęć innych niż uliczny handel.Jego osobowość pozostaje zagadką: z jednej strony okazywał wdowie Hutchins pewną „bandycką delikatność” - do tego stopnia, że przed sądem przyznała, iż zapewne ocalił jej życie, a zeznająca na jego korzyść dziewczyna podkreślała radosne usposobienie i atencję okazywaną jednej z jego pacjentek, z drugiej strony jako pierwszy wdarł się do domu i bez namysłu zastrzelił psa i służącego. Względna otwartość angielskiego miejskiego społeczeństwa była zarazem zagrożeniem dla zamkniętej grupy Aszkenazyjczyków, jak i szansą dla jej poszczególnych członków, którzy dzięki językowej i obyczajowej akulturacji mogli szukać w Londynie swojego „nowego” miejsca. Rabin Z. Hirsch dostrzegał pokusy, na które wystawiani byli Żydzi przez społeczność ger toshab (dosłownie „osiadłych obcych”), i zwracał uwagę, że „w tym kraju każdy może czynić publicznie to, na co ma ochotę" ${ }^{44}$. Pozostając w szeroko pojętym kontekście europejskiej kultury Aszkenazyjczyków, można L. Weila przypisać do warstwy, którą w odniesieniu do bardzo od Londynu odległych społecznych realiów chasydzkiej Europy wschodniej nazywano me-madregah shiniyah, tj. ,inteligencji drugorzędnej”, grupy złożonej z wędrownych nauczycieli, znachorów i cudotwórców ${ }^{45}$. Dzięki swoim medycznym (podobno chirurga i aptekarza) zdolnościom L. Weil był - w pewnym sensie - ich wielkomiejskim, londyńskim „odpowiednikiem”, a równocześnie - podobnie jak koledzy z bandy - znajdował się $\mathrm{w}$, kulturowym zawieszeniu” definiowanym przez jego żydowskie pochodzenie oraz „angielski” sposób praktykowania zawodu i codziennej egzystencji.

${ }^{43}$ Por. N. Shover, op. cit., s. 540-549.

${ }^{44}$ Cyt. za: C. Duschinsky, op. cit., s. 115. Zob. T. M. Endelman, The Jews of Georgian England, s. $223 \mathrm{nn}$.

${ }^{45}$ Pojęcia w odniesieniu do grupy społecznej związanej ze zjawiskiem prechasydyzmu użył Joseph Weiss, Reshit zemihatah shel ha-derekh ha-hasidit, „Zion” 16, 1951, s. 49-56. 
Zeznania przynoszą migawki z ich życia: picie piwa (i wina) w przydrożnej oberży i miejskich tawernach, wulgarna słowna agresja i przekleństwa, zarówno w czasie napadu, jak w rozmowach z innymi „ludźmi ze środowiska", typowe dla opryszków marzenia o fortunie oraz troska o szybkie uzyskanie swojej doli - obrazy, które stanowią pochodne zjawiska kulturowego wykorzenienia, społecznej marginalizacji i moralnej degradacji. Duchowy przywódca londyńskich Aszkenazyjczyków rabin Hirsch dostrzegał postępujący proces „laicyzacji”, któremu ulegali stołeczni Żydzi: pisał i mówił o zatracaniu wiary, ubieraniu się jak goje (na myśl przychodzi „upudrowany” Weil), goleniu bród, potępiał noszenie peruk i dekolty w sukniach kobiet oraz plagę gry w karty. Ostrzegał: ,,jeśli w szabas polecisz gojce-służącej rozpalić ogień, zaparzyć świeżej herbaty czy kawy, nie zapominaj, że karą za ten grzech, wedle tego, co mówi Talmud, jest pożar twego domu [- - ] z powodu tego grzechu spłonęła Jerozolima" ${ }^{46}$. Podsądni mogli być zdeprawowani, nie byli jednak pozbawieni inteligencji i sprytu. Byli świadomi zagrożenia i starali się mu przeciwdziałać: z jednej strony podważali wiarygodność świadków, z drugiej sprowadzili własnych, chociaż jak mówił sądowi M. Hartogh „po angielsku mówię słabo [--]. Nie mam pieniędzy [na zapłacenie za wezwanie sądowe - P.T.D.], a mógłbym sprowadzić ze dwustu", natomiast A. Weil (przez tłumacza) dodawał, że „tak mnie oczerniono, że przyjaciele zbyt się boją świadczyć na moją korzyść" ${ }^{47}$. L. Weil odczytał sądowi - potwierdzając swoje wykształcenie oraz biegłą znajomość angielskiego - wystylizowane oświadczenie, w którym nie tylko podkreślał własną niewinność, ale oskarżał Lazarusa o przekupność i wcześniej popełniane zbrodnie oraz oszustwa, twierdząc, że w Niemczech wydalono go z wojska $\mathrm{z}$,powrozem” na szyi za fałszowanie pieniędzy, ponieważ był „zwykłym oszustem [common cheat]”. Sprowadzona świadek Sara Heith, w gazetach określona jako „młoda dziewczyna”, zeznała, iż 11 czerwca widziała się z doktorem, który wyznał jej, że to dzień jego urodzin i że spędzi go „Pod Syrenką” w Hackney (słynnej siedemnastowiecznej oberży, pamiętającej czasy Samuela Pepysa). Kiedy sąd wyraził wątpliwość co do aż tak dokładnej pamięci świadka, A. Weil - tym razem ustnie, po niemiecku i przy pomocy tłumacza - przyłączył się do jej zeznania, twierdząc, że i on 11 czerwca pił wino „Pod Syrenką”, a potem w gwałtownych słowach oskarżył D. Isaacsa i przede wszystkim S. Lazarusa, którego przezywał „ślepym Zelickiem” (zapewne bandycki pseudonim), zarzucając mu łgarstwa i oszustwa, a zeznania obu za niewarte

${ }^{46}$ Cyt za: C. Duschinsky, op. cit., 9, 1918, s. 112 (cyt. i tłum. - P.T.D.), 114, 117, 130.

47 OBSP. 
wysłuchiwania przez żaden sąd. Oskarżył też jednego z nich o kradzież diamentu należącego do arystokraty, lorda Baltimore ${ }^{48}$. Pozostali także zarzekali się, że byli niewinni i nigdy nie byli w Chelsea: ,jestem niewinny jak dziecko" powtarzał zagrożony stryczkiem H. Lazarus. Jak relacjonował miesięcznik „Lady's Magazine”, pismo tworzone specjalnie z myślą o żądnych sensacji londyńskich czytelniczkach, „,wszyscy zaprzeczali [i mówili], że są zupełnie niewinni" ${ }^{49}$. Oskarżeni szukali wsparcia u sąsiadów lub znajomych, którzy mogliby zapewnić im alibi. Pani Kelley (wedle gazet: Killic), właścicielka sklepu z owocami przy Petticoat Lane, ulicy już od XVII w. związanej z handlem starzyzną, świadczyła na korzyść S. Portera, który za 10 szylingów miesięcznie wynajmował u niej ponad rok mieszkanie. Określiła go jako handlarza używanymi ubraniami i zeznała, że 11 czerwca do dziesiątej wieczorem jadła z nim w swoim sklepie kolację (złożoną wedle doniesień prasowych z chleba i sera). Świadek Ann Sherwood, której „mamma” miała lombard przy Tooley street, uznała go za „bardzo przyzwoitego człowieka”. Do kręgu znajomych Weila należały też młoda niemiecka Żydówka Phoebe oraz Fanny, żona H. Lazarusa (i kochanka Abrahama Lineville'a).

W angielskiej praktyce sądowej pojawianie się świadków obrony, tzw. character witnesess, których rolą było ukazanie pozytywnych stron charakteru podsądnego, zostało zapoczątkowane w XVIII w. Moralna laurka, podobnie jak czynniki, których brak w procesie bandy Weila - młody wiek, pomieszanie zmysłów czy skrajna nędza - bywały powodami złagodzenia wyroku ${ }^{50}$.

Kolejnym elementem, który dawał oskarżonym szanse uniknięcia stryczka, była późna godzina napadu i panujące już ciemności. Pani

${ }^{48}$ Skojarzenie z nazwiskiem tego arystokraty nie musiało działać na korzyść. W 1768 r. zakończył się szeroko komentowany w Londynie proces lorda Baltimore, erotomana-mizantropa znanego z „orientalnych gustów”, o uprowadzenie i uwiezienie londyńskiej modystki, którą nakłaniał do nierządu. Zob. W. Shugg, The Baron and the Milliner: Lord Baltimore's Rape Trial as a Mirror of Class Tensions in Mid-Georgian London, „Maryland Historical Magazine” 83, 1988, 4, s. 310-330. Wzmianka o wydaleniu z wojska (zapewne w okresie wojny siedmioletniej) może też wskazywać, że Weil obracał się w środowisku felczerów wojskowych, w którym funkcjonowało wielu Żydów, np. w armii carskiej za Piotra I. Ponadto po 1721 r. na obszarze Rzeszy Niemieckiej Żydom zezwolono na studiowanie medycyny, zob. E. Kossoy, A. Ohry, The Feldshers: Medical, Sociological and Historical Aspects of Practitioners of Medicine with Below University Level Education, Jerusalem 1992, s. 68-71, 144-145.

${ }^{49}$ "That they were totally innocent”, ,Lady's Magazine” 2, 1771, s. 271.

${ }^{50}$ OBSP. Por. T.E. Endelman, The Jews of Georgian England, s. 198 n.; B. Lemire, Consumerism in Preindustrial and Early Industrial England: The Trade in Secondhand Clothes, „Journal of British Studies” 27, 1988, 1, s. 1-24; P. King, Decision-Makers, s. 42 nn.; D. Y. Rabin, Identity, passim. 
Hutchins wspomniała, że po wtargnięciu do domu bandyci zgasili świecę, którą trzymała w ręce, a sami posługiwali się małymi woskowymi lampkami (brązowy wosk znaleziono na kapeluszu H. Lazarusa). Całe zajście rozgrywało się zatem w ciemnościach nocy, rozpoznanie napastników było trudne: jeden służący nie żył, drugiemu udało się uciec, kobiety sterroryzowano i związano. Nawet bandyci nie do końca orientowali się w mroku: okrzyk dwójki stojącej na czatach wskazywał, że nie widzieli, kto stara się wyjść z domu „kuchennymi” drzwiami. Sąd był świadomy problemu, jaki stanowiła poprawna identyfikacja, i nawracał do tego wątku przy każdym przesłuchaniu. Zeznanie karczmarza, który „ze względu na słabości” (był krótkowidzem) nie potrafił rozpoznać (co prawda po dwóch miesiącach) swoich aż nader ciekawskich gości, tworzyło niepokojącą perspektywę, że wątpliwości mogą przeważyć nad dowodami. Sędzia zapytał wprost panią Hutchins o jej wątpliwości co do tożsamości napastników. Wedle niektórych relacji prasowych nie miała wątpliwości, ale przytoczono także jej zeznanie, iż „wywodzi to z tego, że możliwe jest, że jedna twarz podobna jest do innej, a wszyscy zatrzymani byli równie wysocy, a kiedy weszli do jej domu, ubrani byli w rudego koloru płaszcze, które sięgały im do pięt"51.

Londyn w XVIII w. był miastem niebezpiecznym. Brak zorganizowanej i „zawodowej” policji powodował, że państwo broniło się przed „falami przestępczości" mnożeniem i zaostrzaniem statutowych kar. Jak pisał Douglas Hay, „krwawy entuzjazm” ustawodawców - Izby Gmin - praktycznie uniemożliwia policzenie liczby „paragrafów”, na podstawie których przestępcę można było skazać na śmierć przez publiczne powieszenie ${ }^{52}$. Współczesne badania podkreślają, że wizerunek bezlitosnego sądu mierzony liczbą ferowanych i w rzeczywistości wykonanych wyroków śmierci $-23 \%$ w latach siedemdziesiątych XVIII w. oraz $31 \%$ w okresie 1782-1787 r. (orzecznictwo sądów płd. Anglii) - nie powinien $-\mathrm{z}$ jednej strony - podważać ustaleń mówiących o znacznie większej liczbie kar bardziej łagodnych, a z drugiej narzucić przekonania, że gardłem karano

51 „being questioned from the bench what were her doubts respecting the identity of the persons she said, they were founded merely on the possibility of one human face resembling another and the prisoners being three of them equally tall and disguised in reddish-coloured great coats which reached to their heels”, „Town \& Country Magazine" 3, 1771, s. 651. OBSP.

52 D. Hay, op. cit., s. 50. Pojecia „fali przemocy” (crime wave) użyli w 1986 r. Joanna Innes i John Styles, charakteryzując - przewrotnie - nie tyle osiemnastowieczne paroksyzmy sądowej gorliwości, ile dwudziestowieczny wybuch zainteresowania oświeceniową przestępczością. Zob. J. Innes, J. Styles, The Crime Wave: Recent Writing on Crime and Criminal Justice in Eighteenth-Century England, ,Journal of British Studies” 25, 1986, s. $380-435$. 
tylko przestępców skazanych za morderstwa i zabójstwa ${ }^{53}$. Surowo, ale oszczędnie (tj. z zamianą na deportację) wymierzana kara śmierci w większości przypadków dotyczyła przestępstw skierowanych nie tyle przeciw życiu i zdrowiu, ile przeciwko mieniu i własności (tzw. property crime), dotyczyła więc złoczyńców, którzy kradli, rabowali podróżnych i włamywali się do domów oraz obracali kradzionymi przedmiotami. Na szubienice szedł zarówno kieszonkowiec, który sprytnie wyłuskał z kieszeni zegarek, jak i złodziejka suszącej się na okiennicy bielizny, nie mówiąc już o takich włamywaczach, jak L. Weil i jego wspólnicy. P. King podkreślał, że dla im podobnych, tak samo jak dla rabusiów działających na gościńcach, osiemnastowieczny wymiar sprawiedliwości rzadko znajdował okoliczności łagodzące ${ }^{54}$. Zastrzelony służący wydaje się jakby krwawym dopiskiem do sprawy brutalnego napadu, włamania i popełnionej kradzieży, chociaż akt oskarżenia dotyczył popełnionego morderstwa. Pierwsze doniesienie prasowe mówiło, że został postrzelony w głowę i jest bliski śmierci, w czasie procesu osoba J. Slewa (jego nazwisko - od ang. slay, zabijać - można odczytywać jako ponury żart językowy) ukazana była nieco marginalnie - okrwawiony i postrzelony (pod ramieniem) pojawił się na schodach po ucieczce napastników, kula zapaliła na nim koszulę (wdowa zgasiła płomień), zamienił z panią Hutchins kilka słów (twierdząc, że umiera: „declaring himself a dead man”) i padł (ale z prasy już nie dowiadujemy się, czy bez życia) $)^{55}$. Motyw mordu urywa się, a dalszy przebieg procesu oraz prasowych relacji - dotyczył już innych wątków: drobiazgowej próby identyfikacji przestępców oraz wyliczenia, skatalogowania i przypisania złodziejom skradzionych przedmiotów. Na pierwszym miejscu znajdują się przedmioty, a nie ludzie. Można odnieść wrażenie, że ważniejsze od życia sługi było odszukanie porcelanowego kubka, kosztownego - to prawda - zegarka (paser sprzedał go za ok. 6 gwinei), a przede wszystkim ustalenie losów sztuki jedwabiu, prześledzenia i odtworzenia łańcucha rąk, które delikatnej materii dotykały ${ }^{56}$. Nawrócony paser przyznał się,

${ }^{53}$ P. King, Decision-Makers, s. 50.

${ }^{54}$ Ibidem, s. 36-38, 46. O potrzebie badania społecznych uwarunkowań spraw i wyroków wydawanych w sprawach wykroczeń (non-lethal violence) przez sądy niższej instancji pisał P. King, The Summary Courts and Social Relations in Eighteenth-Century England, „Past \& Present” 2004, 183, s. 125-172.

55 „The London Magazine” 40, 1771, s. 618; „Town \& Country Magazine” 3, 1771, s. 652 nazywa go jednak (wedle zeznania drugiego służącego) „zmarłym” (diseased man) i przytacza jego słowa „I am a dead man”. Tylko „The Scots Magazine” 33, 1771, s. 700 zaznaczył w czerwcowej relacji o napadzie, że Slew zmarł z ran (,the wounded man died last night"). Z zeznania Stone'a wynika, że zmarł o trzeciej następnego dnia, OBSP.

${ }^{56}$ Porcelanowy kubek wskazuje na pochodzenie z zamkniętej w 1770 r. manufaktury porcelany w Chelsea (produkcję przeniesiono do Derby), która specjalizowała się 
komu sprzedał ów cenny materiał. Sprowadzona na rozprawę pani $\mathrm{Ca}-$ verner, która przerobiła jedwab na modną i elegancką sukienkę (sack), rozpoznała materiał po plamach. Corpus delicti przedstawiono w sądzie i mimo że Caverner miała kłopot z odkryciem defektu, to kolejny „biegły", farbiarz Joseph Eyre, który pierwotnie sprzedał wdowie ten materiał, wyjaśnił, że początkowo miała powstać z niego sukienka dla jego żony, ale w czasie próby rozprasowania fałdów doszło - przypadkowo do poplamienia jedwabiu tłuszczem z żelazka ${ }^{57}$.

Ławie przysięgłych - po 8 godzinach słuchania - zajęło już tylko $20 \mathrm{mi}-$ nut ustalenie wyroku: czterech oskarżonych uznano za winnych, a dwóch, Hartogh'a i Harryego - z braku dowodów - uniewinniono.

Sprawa napadu na wdowę Hutchins pozwala na sformułowanie kilku uwag natury ogólnej. Napad w Chelsea nabrał wielkiego rozgłosu, był szczegółowo relacjonowany i komentowany. W celu wytropienia sprawców sędzia Fielding sięgnął, za zgodą rządu, nie tylko do zwyczajowego arsenału środków, ale wyznaczył też nagrodę 50 funtów za pomoc w schwytaniu bandytów, a jego policjanci nie „odpuścili” do końca: w tydzień po egzekucji w ich ręce wpadł Abraham Lineville (zwany Ninivah), wspominany w czasie procesu jako ten, który lufą pistoletu wybił ząb wdowie Hutchins. Szersze implikacje - wzrost nastrojów antyżydowskich - były dobrze rozumiane zarówno przez aszkenazyjską wspólnotę, która starała się odseparować od przestępców (dwa dni przed egzekucją rzucając na nich klątwę), jak i przez wymiar sprawiedliwości, którego przedstawiciele zaznaczali, że ekscesy kilku nie mogą rzutować na całą społeczność. Stereotyp zagrożenia wzrostem żydowskiej przestępczości - zjawiska dostrzeganego w Londynie po 1760 r., ale statystycznie marginalnego przyczynił się jednak do utrzymujących się antyżydowskich nastrojów. Przez wiele następnych lat zwrot „go to Chelsea" rzucony na ulicy w kierunku Żyda był wstępem do słownej, a czasem i fizycznej agresji ${ }^{58}$.

w produkcji przedmiotów domowego użytku (zastawy stołowej i herbacianej) oraz ozdobnych rokokowych figurynek i tzw. zabawek - wyrafinowanych gadżetów, np. buteleczek i puzderek na pachnidła, często wręczanych jako prezenty, por. Y. Hackenbroch, Chelsea Porcelain: Some Additions to the Irwin Untermeyer Collection, „The Metropolitan Museum of Art Bulletin" 20,1971, 10, s. 405-417.

57 OBSP; „Town \& Country Magazine” 3, 1771, s. 653.

58 „Yesterday [16 XII 1771 - P.T.D.] three Jews were taken in Whimple-court, Petticoat-lane, on a suspicion of being accomplices in the murder and robbery at Mrs. Hutchins's, near Chelsea; Nineveh, the fellow who forced the pistol to her mouth, by which he cut her lip, and loosened a tooth, is one of the number; they were carried before Sir John Fielding who committed them for further examination”, „The Oxford Magazine” 1771, 7, s. 238. Por. T. M. Endelman, The Jews of Georgian England, s. 198-201, 203. 
Przebieg procesu i relacje o nim w prasie ujawniają zakres geograficzny działania bandy Weilów. Przestępcy mieszkali w starym centrum stolicy, w Londynie infra muros, blisko synagogi położonej na wschodzie miasta. Potrafili jednak łatwo przedostać się przez zatłoczony Londyn - na pewno nieobca im była topografia oberży - i przemieszczać się (zapewne pieszo) o wiele kilometrów, nie tylko do położonej na zachodzie podmiejskiej wsi Chelsea, ale także - wykorzystując „komunikację publiczną” (karetki pocztowe) - do innych miast (Birmingham i Coventry), gdzie prowadzili nie tylko paserskie interesy. Porównanie miejsc wymienionych w czasie procesu z tymi, gdzie doszło do włamań, adresów zamieszkania, ukazujących topografię społecznych kontaktów (okazuje się, że nie tylko wewnątrz żydowskiej diaspory), z miejscami wybranymi jako cele napadu, potwierdza zdroworozsądkową i praktyczną zasadę, że kradnie się tam, gdzie się nie jest znanym. Druga uwaga dotyczy samej grupy przestępczej - była ona zbudowana wokół herszta (a może raczej hersztów) na podstawie więzi osadzonych w przestrzeni dzielnicowej wspólnoty zamieszkania, wspólnych doświadczeń wyniesionych jeszcze z kontynentu (np. służby w wojsku), codziennych kontaktów wypracowanych dzięki obrotowi kradzionym towarem i wreszcie - choć cecha to szczególna - wspólnoty pochodzenia, języka i wiary. Po trzecie wreszcie trzeba zwrócić uwagę na sam zapis źródłowy i jego mutacje. Konfrontując protokół przesłuchań z relacjami w gazetach, odnajdujemy wiele przebarwień i nieścisłości. Powinniśmy przyjać je bez zdziwienia, zwracając jednak uwagę na to, że zapisane (i wydrukowane) słowa miały do spełnienia inne funkcje: protokół, notowany ręką sądowego skryby, drobiazgowo relacjonował przebieg rozprawy, relacja prasowa - mniej czy bardziej dokładna - odgrywała rolę informacyjną, „ostrzegawczą”, a przede wszystkim dydaktyczną. Ten ostatni element - streszczony we wszystkich gazetach epilog sprawy - dotyczył kary za zbrodnie i wykonania wyroków śmierci.

Jak donosił dobrze poinformowany „The Oxford Magazine”, w dniu 9 grudnia czterech skazanych powieszono w zwyczajowym miejscu londyńskich kaźni, na skrzyżowaniu Tyburn. „Ich żonom i dzieciom pozwolono pożegnać się na dziedzińcu [więzienia - press yard] zanim wyruszyli. Pod szubienicą nie było duchownego, ale na dziedzińcu [więzienia] dał on każdemu książkę. Kiedy dotarli na miejsce kaźni, modlili się i przez kwadrans śpiewali razem"59. Jeszcze lepiej poinformowany albo bardziej

59 „Their wives and children were admitted into the Press-yard to take their leave of them before they set out. The Priest did not attend at the gallows, but gave each of them a book in the Press-yard. When they came to the place of execution, they 
sprawą zainteresowany „The London Magazine” informował, że powieszono ich o pół do jedenastej. Ciała przekazano cechowi chirurgów w celu przeprowadzenia sekcji (dissection), a trup (a raczej szkielet) L. Weila lekarza i włamywacza - miał zostać eksponatem (anatomized) w siedzibie cechu ${ }^{60}$.

\section{A Piece of Lemon-Silk: Widow Hutchins, the Jews, and Organized Crime in XVIIIth Century London}

The article is informed by Old Bailey Proceedings of the case against a Jewish criminal gang, which in summer 1771 broke into a house of a well-to-do Chelsea widow. The case received much publicity: the press reports culled from major monthlies are used to corroborate the basic narrative, and its mutations, which - in turn exemplify several themes, such as gang violence and criminal associations in the city, the English anti-Semitism and attitudes toward the newcomers, the Askenazi Jews, and the urban commodity-based market consciousness with its notions of security - important in shaping the late XVIIIth century London culture.

prayed and sung about a quarter of an hour amongst themselves”, „The Oxford Magazine" 1771,7, s. 237.

${ }^{60}$ „The London Magazine” 40, 1771, s. 619. 